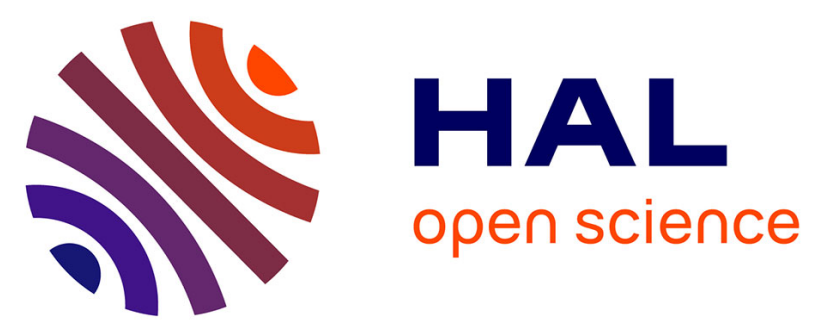

\title{
Diversity and taxonomic revision of tribes Rhipileae and Rhipiliopsideae (Halimedaceae, Chlorophyta) based on molecular and morphological data
}

\author{
Laura Lagourgue, Claude E Payri
}

\section{- To cite this version: \\ Laura Lagourgue, Claude E Payri. Diversity and taxonomic revision of tribes Rhipileae and Rhip- iliopsideae (Halimedaceae, Chlorophyta) based on molecular and morphological data. Journal of Phycology, In press, 10.1111/jpy.13186 . hal-03232042}

\section{HAL Id: hal-03232042 \\ https: / hal.sorbonne-universite.fr/hal-03232042}

Submitted on 21 May 2021

HAL is a multi-disciplinary open access archive for the deposit and dissemination of scientific research documents, whether they are published or not. The documents may come from teaching and research institutions in France or abroad, or from public or private research centers.
L'archive ouverte pluridisciplinaire HAL, est destinée au dépôt et à la diffusion de documents scientifiques de niveau recherche, publiés ou non, émanant des établissements d'enseignement et de recherche français ou étrangers, des laboratoires publics ou privés. 
DIVERSITY AND TAXONOMIC REVISION OF TRIBES RHIPILEAE AND

RHIPILIOPSIDEAE (HALIMEDACEAE, CHLOROPHYTA) BASED ON MOLECULAR AND MORPHOLOGICAL DATA $\left({ }^{1}\right)$

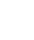

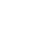

$$
\text { Laura Lagourgue (²) }
$$

Sorbonne Universités, UPMC Univ Paris 06, IFD, 4 Place Jussieu, 75252 Paris Cedex 05, France

UMR ENTROPIE (IRD, UR, UNC, Ifremer, CNRS), Institut de Recherche pour le Développement, B.P. A5 Nouméa Cedex, Nouvelle-Calédonie, 98848, France.

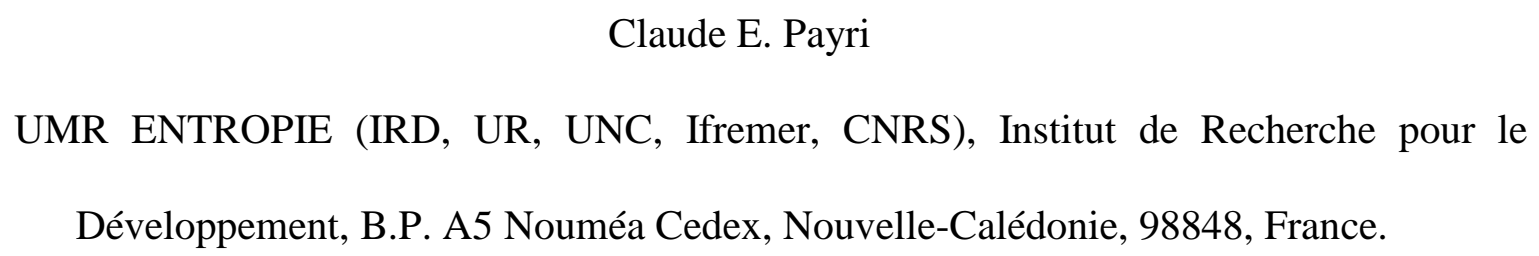
Développement, B.P. A5 Nouméa Cedex, Nouvelle-Calédonie, 98848, France.

(²) Corresponding Author: laura.lagourgue@ird.fr, (+687) 518710

RUNNING TITLE: Rhipileae and Rhipiliopsideae diversity and taxonomy

(1)

\section{ABSTRACT:}

Genera and species of the tribes Rhipileae and Rhipiliopsideae are abundant in most coral reef ecosystems worldwide. However, the group has been largely overlooked, and very little genetic data is available to accurately assess its diversity, phylogenetic relationships, and geographical distribution. Our study provided an in-depth reassessment of tribes Rhipileae and Rhipiliopsideae based on a species-rich dataset and the combination of molecular species 
delimitation, multilocus phylogenetic analyses (tufA, rbcL and 18S rDNA), and morphoanatomical observations. Our results revealed an unexpected diversity of 38 morphologicallyvalidated species hypotheses, including 20 new species, two of which are described in this paper and one resurrected species (Rhipilia diaphana). Based on our phylogenetic results we proposed to redefine the genera Rhipilia and Rhipiliopsis and described two new genera, Kraftalia gen. nov. (Rhipileae) and Rhipiliospina gen. nov. (Rhipiliopsideae). Finally, we validated Rhipiliella Kraft and included it in tribe Rhipileae. Although Rhipilia and Rhipiliopsis have a pantropical distribution, none of the species studied here appeared cosmopolitan; instead, they have restricted distributions.

KEYWORDS: Chlorophyta; Kraftalia gen. nov.; macroalgae; phylogeny; Rhipiliaceae; Rhipiliospina gen. nov; siphonous; species delimitation. 
Abbreviations: ABGD, automatic barcode gap discovery; AIC, akaike information criterion;

39 BEAST, bayesian evolutionary analysis sampling trees; bGMYC, bayesian general mixed

40 yule coalescent; BI, bayesian inference; bs, bootstraps;ESS, effective sample size; GMYC,

41 general mixed yule coalescent; GTR, general time reversible; K80, kimura model; MCCT,

42 maximum clade credibility tree; MCMC, markov monte carlo chain; ML, maximum

43 likelihood; mPTP, multi-rate poisson pree process; nov., nova/novum; PP, posterior

44 probabilities; PSH, primary species hypothesis; PTP, poisson tree process; RAXML,

45 randomized axelerated maximum likelihood; SSH, secondary species hypothesis; sp., species;

46 s.s., sensu stricto; tufA, elongation factor Tu. 


\section{INTRODUCTION}

In algae, traditional taxonomy has long been based on morphological characters with, as a corollary, a multitude of poorly defined taxa or nomina dubia and a classification that only partially reflects the natural relationships among taxa (De Clerck et al., 2013; Leliaert et al., 2014). In current works, the contributions of DNA sequence data combined with morphological and often geographical criteria have made it possible to revise taxonomic ambiguities (e.g., Vieira et al., 2014; Caragnano et al., 2018; Hughey et al., 2019). The siphonous green macroalgae Bryopsidales are a good example of a group for which morphologically based taxonomy has led to several problems and has been revised in several works, including the resurrection of old unused species names (e.g., Tydemania gardineri, Lagourgue et al, 2020), the synonymy of others (e.g., in Codium, Verbruggen et al., 2007), or the description of new taxa in response to the cryptic diversity revealed by DNA analyses (e.g., whole order (Verbruggen et al., 2009a), Udoteaceae (Lagourgue and Payri, 2020) or Halimeda (Cremen et al., 2016)). Sequence-based species delimitation approaches are recognized as powerful tools to study species diversity (Luo et al., 2018). Many methods have been developed, either based on genetic distances or on phylogenetic trees. The species delimitation process can be used independently for the purpose of referencing genetic diversity, or as part of a broader integrative taxonomic approach to assist in both delimitation and species identification (e.g., Bond and Stockman, 2008; Hotaling et al., 2016; Mason et al., 2016). Species delimitation approaches have been demonstrated as the best tool to assess macroalgal diversity (e.g., Leliaert et al., 2014), and within the green algae, these tools have been successfully used for groups such as Chlorella-like species (Zou et al., 2016), Boodlea (Leliaert et al., 2009), the Udoteaceae (Lagourgue et al., 2018; Lagourgue and Payri, 2020) or Ulvophyceae (Sauvage et al., 2016). Species delimitation methods have also proved successful to detect cryptic species or, conversely, phenotypic plasticity (e.g., Vieira et al., 
2014), which is critical for taxonomic baseline data, biodiversity inventories, or to better understand ecological, physiological or evolutionary processes. Through phylogenies and character state mapping, DNA sequence data are also essential for classifications to reflect natural relationships and for studying the evolution of morpho-anatomical characters across lineages. In particular, comparative phylogenetic methods (PCMs) are designed to study how an organism's morpho-anatomical characters or traits have changed over time and which have influenced speciation or extinction events. Although these methods are very powerful, the evolution of morphological characters has been inferred on phylogenies only in a few studies of Bryopsidales (e.g., Verbruggen et al. (2007) on Codium; Lagourgue and Payri (2020) on Udoteaceae; Verbruggen et al. (2009b) on Halimeda; and Payri and Verbruggen (2009) on Pseudocodium). Finally, phylogenetic inference has also been used to decipher biogeographical history, using distribution data to estimate the lineages evolution in space and time (e.g., Vieira et al., 2017, Leliaert et al., 2018, or Vieira et al., 2021).

Rhipileae and Rhipiliopsideae species are siphonous green macroalgae whose geographical distribution is mainly tropical and associated with coral reef ecosystems. These species inhabit a wide variety of habitats from the surface to $150 \mathrm{~m}$ depth (Eiseman and Earle, 1983). They are found in seagrass meadows, lagoons, reef patches, reef slopes, and some endolithic species are even found in coral skeletons (Marcellino and Verbruggen, 2016). Except for two species, Rhipilia tomentosa and Johnson-sea-linkia profunda, recorded from the Caribbean region, most species are distributed in the Indo-Pacific region.

The family Rhipiliaceae was merged with the family Halimedaceae by Cremen et al. (2019) and its species transferred to two tribes: Rhipileae and Rhipiliopsideae. The former, described initially by Hillis-Collinvaux (1984), was emended by Cremen et al. (2019) and now includes species of Rhipilia, the monospecific genus Johnson-sea-linkia, Pseudochlorodesmis sp., Boodleopsis pusilla, and Boodleopsis sp. Cremen et al. (2019) also proposed the new tribe 
Rhipiliopsideae to accommodate two species: Rhipiliopsis peltata and Callipsygma wilsonis.

The Rhipiliaceae was initially proposed by Dragastan et al. (1997) to distinguish the genera Rhipilia, Rhipiliopsis and Rhipiliella, and the fossil genus Baratangia, from other members of the Udoteaceae. Molecular phylogenetic analyses confirmed that Rhipilia and Rhipiliopsis are genetically distinct from Udoteaceae (Verbruggen et al., 2009c), while in the absence of genetic data, Rhipiliella was maintained within the Udoteaceae. Additionally, phylogenetic studies, including representative Rhipilia and Rhipiliopsis, revealed that none of these genera was monophyletic (Verbruggen et al., 2009a, c; Cremen et al., 2019). Cremen et al. (2019) also showed that Rhipiliaceae was polyphyletic, as Rhipilia and Rhipiliopsis do not form a monophyletic clade, and Rhipiliopsis rather branches as a sister lineage to Halimeda and Callipsygma. They resurrected Johnson-sea-linkia to accommodate Rhipiliopsis profunda and resolved the polyphyly of Rhipiliopsis. Tribes Rhipileae and Rhipiliopsideae are not as wellknown as the closely related Udoteae, Halimedeae or Caulerpaceae, for which unexpected species diversity has been revealed (Verbruggen et al., 2005a, b; Sauvage et al., 2013; Lagourgue and Payri, 2020). Indeed, most of the Rhipileae and Rhipiliopsideae species have been described from morphological characters only, and the DNA sequence data available for these lineages is limited to five species of Rhipilia, two species of Rhipiliopsis and one species of each Johnson-sea-linkia and Callipsygma, most of which are represented by a single marker.

Morphologically, species of the former family Rhipiliaceae are non-calcified and they consist of an erect cylindrical stipe, sometimes very small (or even indistinct), anchored to the substratum by a rhizomatous base and topped with siphonous filaments (i.e., siphons). These siphons are either free or joined into a flabelliform, peltate or cyathiform frond. Initially, the family was characterized by the presence of particular secondary structures that allow the adjacent siphons to adhere more or less firmly to each other and known as tenacula 
in Rhipilia and papillae in Rhipiliopsis. Rhipilia includes 12 currently recognized species (Guiry and Guiry, 2020) and is morphologically diverse, ranging from fronds composed of free siphons (e.g., R. penicilloides or $R$. coppejansii), to more or less fan- or funnel-shaped (infundibuliform) blades that can be thin or compact (e.g., R. tomentosa/ R. orientalis). The tenacula of Rhipilia species can be of various shapes (forked, pronged, hook-shaped, bent, or discoid) and are observed throughout the frond or only at the base in species with free siphons. Rhipiliopsis currently includes 19 species (including Johnson-sea-linkia profunda, Guiry and Guiry, 2020) that are much smaller in size and more delicate than Rhipilia species. Rhipiliopsis species consist of a mono- or multisiphonous stipe and a mono- or pluristromatic blade (flabellate, peltate, or cyathiform). The papillae are less developed than the tenacula of Rhipilia but give a cohesive and net-like appearance to the blade. Four types of lateral cohesion have been described by Coppejans et al. (1999): papillae with or without a thickening ring, direct longitudinal contact between the siphons or adhesion by differentiated apices of siphons. Finally, Rhipiliella was proposed by Kraft (1986) to accommodate specimens with deciduous blades. The only species, Rhipiliella verticillata, is characterized by whorls of abscission scars left on the stipe by successively lost deciduous blades.

To date, these lineages are poorly documented genetically, likely because of their small size or their ecology, as they preferred habitats like cracks or crevices that are difficult to access (particularly Rhipiliopsis and Rhipiliella). The main objective of our study was to reassess the diversity and systematics of Rhipileae and Rhipiliopsideae using a combined morphological and molecular approach applied to a large specimen dataset, and to meet the different objectives of a multidisciplinary approach, using integrative taxonomy. A rich collection of specimens collected from most of the geographical range of the relevant species was used to acquire new molecular and morphological data. Using several methods, including molecular species delimitation, multilocus phylogenetic analyses (tufA, $r b c \mathrm{~L}$ and $18 \mathrm{~S}$ rDNA), 
and morpho-anatomical observations, we aimed to (1) explore species diversity, (2) analyze species phylogenetic relationships, and, where necessary, (3) resolve taxonomic ambiguities within these lineages.

\section{MATERIAL AND METHODS}

\section{Sampling}

A total of 587 Rhipileae and Rhipiliopsideae samples were included in this study. They were collected by the authors and several collaborators using SCUBA at various localities in the Indo-Pacific region (Table S1 in Supplementary Information). Vouchers were pressed-dried on herbarium sheets and mainly housed at NOU, GENT, MEL, and PERTH (herbarium abbreviations follow Thiers (2021), continuously updated). Subsamples were preserved in 95 \% ethanol and silica gel for DNA analyses, and in a formaldehyde solution (5\% in seawater) for morpho-anatomical studies.

\section{DNA extraction, amplification, and sequencing}

Extractions were conducted using the Plant mini Kit (Qiagen Inc, Valencia, CA, USA) for Rhipilia and CTAB protocol for all other genera. Two chloroplast markers, tufA and rbcL, and the 18S rDNA nuclear gene were sequenced using previously published primers (Kooistra, 2002; Lam and Zechman, 2006; Verbruggen et al., 2009c; Händeler et al., 2010) (see Table S2 in Supplementary Information). In some instances, the $r b c L$ and $18 S$ rDNA genes were amplified in two fragments ( $r b c L 5$ ' and $r b c L 3$ '; 18S5' and 18S3'). PCR reactions were conducted in a final volume of $25 \mu \mathrm{L}$ including $1 \mathrm{X}$ of AmpliTaq Gold 360 Master Mix (Applied Biosystems), $0.4 \mu \mathrm{M}$ of each primer, $3 \%$ of dimethylsulfoxyde (DMSO), $0.4 \mu \mathrm{g}$. $\mu \mathrm{L}^{-1}$ of bovine serum albumin (BSA) and 1 ng. $\mu \mathrm{L}^{-1}$ of DNA. PCR programs follow Lagourgue et al. (2018), and the Sanger sequencing reaction was carried out by Genoscreen 
172 (Lille, France). Sequences were edited with Geneious version 7.1.9

173 (http://www.geneious.com, Kearse et al., 2012). Additional sequences were retrieved from

174 GenBank (18 tufA, 16 rbcL, and one 18S rDNA) and added to our dataset. All sequences

175 were aligned for each marker separately using the MUSCLE algorithm available in the

176 Geneious software. The CLUSTAW algorithm was also used for DNA regions that were

177 difficult to align (e.g., 18S rDNA gene). Species delimitation methods were performed on the

178 two chloroplast datasets independently, while phylogenetic reconstructions were performed

179 on a multilocus (tufA, rbcL and 18S rDNA) concatenated matrix.

\section{Phylogenetic reconstructions}

182 Phylogenetic reconstructions for species delimitation analyses were performed for each marker individually, selecting only distinct haplotypes in each dataset, and using maximum likelihood (ML) and Bayesian inference (BI) for ultrametric trees. The datasets were analyzed with Partition Finder v1.1.0 to determine the most suitable evolutionary models according to the Akaike information criterion (AIC). For the evaluation of partition schemes, $r b c L$ was tested both as one entire marker and as two distinct datasets (rbcL5' and rbcL3'; i.e., the twofragment sequencing scheme) because of differences in sequencing success and sampling sizes. ML trees were reconstructed in RAXML (Stamatakis, 2014) on the CIPRES web portal (Miller et al., 2010) (see Table S3 in Supplementary Information for more details and analyses parameters). Bayesian ultrametric trees were computed using BEAST (Drummond et al., 2012). The global clock hypothesis was rejected (Likelihood ratio test in MEGA 6,

193 Tamura et al., 2013), and the two analyses were performed under a relaxed lognormal molecular clock associated with a coalescent constant size tree prior, as recommended by Monaghan et al. (2009). For each run, the convergence of the Markov Chains Monte Carlo (MCMC), and the effective sample sizes (> 200) were checked in Tracer v.1.6 (Rambaut and 
Drummond, 2007). Runs were then combined using Log Combiner without the first $10 \%$ generations, removed as burn-in. The Maximum Clade Credibility Tree (MCCT) was then calculated using Tree Annotator (included in the BEAST package).

For the final phylogenetic analyses, ML and BI reconstructions were performed on multilocus matrices (tufA, rbcL, and 18S). The first dataset (i.e., dataset \#1 in Table S3) included several representative members of the suborder Halimedineae (data detailed in Table S1 in Supplementary Information) to assess the taxonomic position and composition of the tribes. Two other datasets were created to represent the Rhipileae (dataset \#2) and Rhipiliopsideae (dataset \#3) tribes, including only one specimen per species for supra-generic level analyses. Finally, for analyses at the genus level, datasets with several representatives per species were assembled (datasets \#4 to 7), provided that sequences were available for at least two of the three markers - except for Rhipilia tomentosa and Rhipiliopsis reticulata, which were not present in our collection, and for which only one sequence each was available on GenBank (rbcL and 18S, respectively). Boodleopsis and Pseudochlorodesmis were excluded from our analyses since both filamentous genera are unresolved (cf. Cremen et al., 2019). Outgroup species, partition schemes, evolutionary models used, and reconstruction parameters for ML and BI trees are detailed in Table S3 (Supplementary Information) for each analysis. Bayesian phylogenetic analyses were performed in MrBayes v.3.2 (Ronquist and Huelsenbeck, 2003) through the CIPRES web portal. The effective sample size (ESS>200) values and the Markov chain Monte Carlo (MCMC) convergence were checked in TRACER v.1.5 (Rambaut and Drummond, 2007) before computing a consensus topology and posterior probabilities. ML reconstructions were conducted in RAXML (Stamatakis, 2014) also through the CIPRES web portal.

\section{Species delimitation}


Five species delimitation methods were used in combination to assess species boundaries. They included four tree-based methods: the General Mixed Yule Coalescent (GMYC) (Pons et al., 2006), its Bayesian implementation: bGMYC (Reid and Carstens, 2012), the Poisson tree process model (hPTP, Zhang et al., 2013) and the Multi-rate version, mPTP (Kapli et al., 2017); and a distance-based method: the Automatic Barcode Gap Discovery (ABGD, Puillandre et al., 2012a). We chose to combine several methods because each is based on different assumptions and models, which allows balancing the biases specific to each of them. Indeed, searching for congruence between the results of each method and between markers allows converging towards the most robust species hypotheses (Carstens and Knowles, 2007; Dupuis et al., 2012; Puillandre et al., 2012b; Carstens et al., 2013; Leliaert et al., 2014; Rannala, 2015). The delimitation methods allowed us to define primary species hypotheses (PSHs), while searching for congruence between markers and methods led us to select secondary species hypotheses (SSHs), which were then confirmed or not using morphoanatomical information. Besides, comparing molecular-based hypotheses to non-genetic data (e.g., morpho-anatomical, ecological) is recommended to corroborate species boundaries (Carstens and Knowles, 2007; Wiens, 2007; Fujita et al., 2012; Carstens et al., 2013; Talavera et al., 2013).

Before applying species delimitation methods, datasets were treated using the Collapsetypes v4.6 perl script (Chesters, 2013) to prevent potential bias linked to identical haplotypes, as recommended by Pons et al. (2006) and Reid and Carstens (2012). Species delimitation methods were then applied as follows:

The ABGD method was applied directly to each marker sequence alignments. The tufA marker was analyzed using the single distance method, with parameter X (relative minimum gap width) set at 0.8 . For $r b c \mathrm{~L}$, two sets of data were analyzed, the $r b c \mathrm{~L} 5$ ' and $r b c \mathrm{~L} 3^{\prime}$ fragments, taking into account the imbalance in the amplification performance of the two 
markers and the sensitivity of the methods to missing data. The Kimura and the Single

Distance methods were applied to the $r b c \mathrm{~L} 5$ ' and $r b c \mathrm{~L} 3$ ' datasets, respectively; parameter $\mathrm{X}$ was set to 0.8 .

GMYC analyses were performed in R (R Development Core Team, 2019) using the "splits" package on the MCCTs obtained with BEAST for each marker. The bGMYC method was applied to a subsample of 100 trees from the same analyses. After exploratory tests, the tufA analysis was run for 30M generations and sampled every 100 generations with a burn-in of 10,000 generations. The $r b c \mathrm{~L}$ analysis was run for $20 \mathrm{M}$ generations and sampled every 100 generations with a burn-in of $5 \mathrm{M}$ generations.

The hPTP method was implemented on the online server (http://sco.hits.org/exelixis/web/software/PTP/index.html) using ML trees and 500,000 generations sampled every 100 generations, for both markers. The mPTP analyses were performed on both the ML and MCCT trees for both markers and via the website (http://mPTP.hits.org) using default settings.

\section{Morphology}

Species identification and observation of morpho-anatomical characters were based on the most relevant literature reference for the group: the work of Gepp and Gepp (1911), including several Rhipilia species and one Rhipiliopsis species; the monograph of Millar and Kraft (2001) as well as the work of N'Yeurt and Keats (1997), and Verbruggen and Schils (2012), among others, for Rhipilia; and mainly the works of Kraft (1986 and 2000), Farghaly and Denizot (1979), Eiseman and Earle (1983), Norris and Olsen (1991) and Coppejans et al. (1999) for Rhipiliopsis. The morpho-anatomical characters observed included the shape of the thallus, the frond, the stipe (Rhipilia) or stalk (Rhipiliopsis) and the stolon (for Rhipilia); the diameter and appearance of the siphons and the type of dichotomies and constrictions; the 
shape, size, frequency, and position of the tenacula (Rhipilia) or papillae (Rhipiliopsis) on the siphons.

\section{RESULTS AND DISCUSSION}

Species delimitation analyses

A total of 906 sequences (tufA: 440 sequences; rbcL: 363 sequences; 18S rDNA: 103

sequences) were successfully produced, to which we added sequences available in GenBank (i.e., for 25 additional specimens). The list of sequences and corresponding specimens and accession numbers are presented in Table S1 (Supplementary Information). The variability of datasets is reported in Table S4 (Supplementary Information). The phylogenetic analyses of the multilocus matrix (tufA, $r b c \mathrm{~L}$, and $18 \mathrm{~S}$ rDNA) at the suborder level (Figure S1) led us to consider three clades for the species delimitation approach: a group corresponding to tribe Rhipileae (including specimens of Rhipilia, Rhipiliopsis and Rhipiliella), a "Rhipiliopsideae group 1” (including specimens of Rhipiliopsis and Callipsygma), and a "Rhipiliopsideae group 2” (including specimens of Rhipiliopsis). We have followed this architecture in subsequent analyses, but it is important to note that the relationships among the different tribes are only weakly supported.

Exploratory species delimitation analyses of tufA and $r b c \mathrm{~L}$ datasets: For the tufA dataset, all lineages combined, a total of 14 PSHs were common to all five methods. A summary of the species delimitation results for the tufA marker for all lineages is presented in Table 1. The detailed results for each lineage (Rhipileae, "Rhipiliopsideae group 1” and "Rhipiliopsideae group 2”) are presented in Supplementary Information (Appendix S1 and Figures S2 to S4). The support values and $a$ posteriori probabilities (PP) associated with the partitions delimited 
by hPTP and bGMYC, respectively, are detailed in Appendix S2 and Table S5

(Supplementary Information).

For the $r b c \mathrm{~L}$ dataset and all groups included, a total of 14 SSHs were common to all five methods (see Appendix S3 and Figure S5 and S6 for detailed results on Rhipileae and Rhipiliopsideae lineages). The summary of species delimitation results are presented in Table 1. The hPTP partitions support values, and the PP of the bGMYC partitions are detailed in Appendix S4 and Table S6 (Supplementary Information).

SSH definition and species name assignation: At the level of markers, a significant number of PSHs were common to all species delimitation methods (Table 1). Thirty-six SSHs were unambiguously defined based on the PSHs common to both markers. Three additional SSHs were more difficult to define due to discrepancies between the two markers. The resolution process is detailed in Table S7.

In total, 39 SSHs were delimited within the Rhipileae and Rhipiliopsideae, of which only 16 could be unambiguously named using morpho-anatomical observations. Two additional SSHs still await confirmation before final species name assignment (SSH20: $R$. sp1 cf. mortensenii; SSH29: R. sp14 cf. echinocaulos). Twenty SSHs could not be assigned to current species and probably represent new species. One SSH (SSH21) was only represented by GenBank sequences and could not be morphologically analyzed. Details about the species assignment of SSHs are available in Figures S2 to S6 (Supplementary Information).

Marker variability and the need to combine them: The chloroplast markers, tufA and $r b c \mathrm{~L}$, were used in the species delimitation approach due to their variability and discriminatory power at the species level, as recognized in previous studies (Verbruggen et al., 2009c; Saunders and Kucera, 2010; Leliaert et al., 2014). In this study, both markers proved to be 
effective in providing species hypotheses and discriminating between species, in addition to being good substitutes for barcodes (i.e., for species delimitation and identification, respectively, sensu Collins and Cruickshank, 2013). The nuclear 18S rDNA marker was more conserved than chloroplast markers and, therefore, not appropriate for species delineation analyses. However, this marker, which has been used in previous studies at various taxonomic levels (Kooistra et al. (2002) for Halimeda, Kazi et al. (2013) for Caulerpa, Lagourgue et al. (2018) for Udoteaceae, Verbruggen et al. (2009a, c) for the Bryopsidales), remained relevant for phylogenetic analyses, in combination with other markers.

The performance of species delimitation methods: The performance of the species delimitation methods depends on the context, particularly the dataset analyzed (Knowles and Carstens, 2007), since all statistical methods are sensitive to a lack of information on intraspecific variability (Puillandre et al., 2012b; Kekkonen and Hebert, 2014). Adding samples or genetic markers leads to improve species signatures (Knowles and Carstens, 2007), helps to resolve ambiguous cases or conversely, may reveal different partition schemes. However, some methods may be biased toward species discrimination and not recognize the phylogenetic signature of speciation, particularly in cases of rapid and recent diversification events (or adaptive radiations), as revealed by short terminal branches in phylogenetic trees (such as GMYC in Kubatko and Degnan (2007) and Luo et al. (2018)). In this study, these biases were observed in the results of (m)PTP and PTP methods when analyzing tribe Rhipileae, and with the PTP method for the analysis of "Rhipiliopsideae group 1”. Conversely, GMYC produced a higher number of partitions than the other methods, but, for tufA, GMYC (and bGMYC) led to species hypotheses that were the closest to those morphologically identified. 
Species delimitation results also directly depend on the selection of genetic markers and their variability. In this study, species delimitation analyses were conducted independently on the two markers, following Kubatko and Degnan’s (2007) recommendations. The combination of several methods in our study revealed a significant congruence between them. In addition, when methods based on genetic distances were found to be congruent with those based on phylogenetic trees, as observed several times during this study, the robustness of SSHs was increased (Ross et al., 2010; Fujita et al., 2012). However, using several methods was necessary, as none of them alone was able to delimit species defined a posteriori. Comparing different methods is important to counterbalance the bias of starting hypotheses, concepts or models, and to overcome the limits inherent in each method, and finally, to define the most likely species hypotheses (Carstens and Knowles, 2007; Dupuis et al., 2012; Puillandre et al., 2012b; Carstens et al., 2013; Leliaert et al., 2014; Rannala, 2015). In addition, taking into account data of different types makes possible the identification of possible differences in the evolutionary signal and is therefore particularly recommended to compare molecular results to non-genetic data, such as the morphological observations used here (Carstens and Knowles, 2007; Knowles and Carstens, 2007; Wiens, 2007; Fujita et al., 2012; Carstens et al., 2013; Talavera et al., 2013).

Morphology remains essential: In our study, morpho-anatomical observations were successfully used to unambiguously validate and assign 16 SSHs to known species and 20 SSHs to new entities and to document the morphological diversity of genera. The identification of SSHs was hampered by the limited genetic data available and erroneous species assignments in published sequences. Direct examination of the sequenced specimens and access to morphological studies were essential to detect misidentifications and to assign SSHs to the correct species. However, besides being time-consuming, the morpho-anatomical 
approach involves particular best practices, such as the availability of type specimens to ensure correct species assignment, or the study of a large number of specimens to accurately document within species polymorphism (see Wiens and Servedio, 2000). Hence, the success of concomitant morphological and molecular approaches presupposes that the morphological and anatomical characters are sufficiently documented.

\section{Phylogenetic relationships}

Global-scale phylogeny (Suborder Halimedineae): Our phylogenetic reconstructions at the scale of the suborder Halimedineae (dataset \#1; cf. Table S3) confirmed that the former family Rhipiliaceae does not form a monophyletic group (Figure S1), corroborating earlier results by Cremen et al. (2019). However, our analysis, which included more samples and species than in previous studies, resulted in three major lineages (Figure S1), and not two as in Cremen et al.’s study, corresponding to: (1) tribe Rhipileae (bs: 100; PP:1) containing the type genus of the tribe: Rhipilia; (2) “Rhipiliopsideae group 1” (bs: 100; PP:1) including the genus Callipsygma (bs: 100; PP:1) and a group of Rhipiliopsis-like specimens; and (3) “Rhipiliopsideae group 2” (bs: 98; PP:1) also containing Rhipiliopsis-like species and branching as a sister lineage to the genus Halimeda (although not well supported: bs: 72; PP: 0.90). These results indicate that the tribe Rhipiliopsideae, erected by Cremen et al. (2019), is likely polyphyletic.

Additionally, Rhipiliopsis species (or at least Rhipiliopsis-like specimens) were found in all three lineages, with the type-species for the genus, $R$. peltata, included in "Rhipiliopsideae group 2”. The polyphyly of the genus was already shown by Cremen et al. (2019), who reinstated the genus Johnson-sea-linkia profunda, the basionym of Rhipiliopsis profunda (tribe Rhipileae), in an attempt to solve the Rhipiliopsis polyphyly. With a more extensive selection of specimens and taxa, our results point out the need for more taxonomic revisions. 
At least another five Rhipiliopsis-like species were found in tribe Rhipileae, 7 in “Rhipiliopsideae group 1”, and 9 in “Rhipiliopsideae group 2”.

Phylogeny of the Rhipileae lineage: Our phylogenetic reconstructions based on the Rhipileae multilocus matrix including one specimen per species (dataset \#2; cf. Table S3) indicated that the tribe can be subdivided into two groups (Figure 1). The first (group 1, bs: 47; PP: 0.98, Fig. 1) is further divided into a strongly supported subclade (A) containing the type and six other species of Rhipilia on the one hand, and (B) four sequences referring to four genera (Rhipilia, Rhipiliopsis, Johnson-sea-linkia and Rhipiliella) on the other hand. The second group consists of several Rhipiliopsis and Rhipilia species (group 2, bs: 99; PP: 1, Fig. 1) Although the polyphyly of the genus Rhipilia was shown previously (Verbruggen et al., 2009a and c), the extent of it is more significant in our study. We found Rhipilia species in three different sections of the tree. One clade contains the type species, $R$. tomentosa. A second clade is composed of five Rhipilia species clustering with four Rhipiliopsis species (group 2, Fig. 1), and R. pusilla represents the third clade.

Following this result, we consider the clade containing the type species, Rhipilia tomentosa, as representing the genus Rhipilia (Group1, B in Figure 1). Species clustering in the second and third sections thus need to be revised and transferred to other genera. Millar and Kraft (2001) proposed various subdivisions for Rhipilia based on the abundance and shape of tenacula, but this classification is not compatible with our results. Indeed, species with both rare (e.g., $R$. penicilloides) and abundant tenacula (e.g., $R$. tomentosa) have been found in the same group. Similarly, the grouping of species according to the shape of the fronds (blade or free siphons) did not produce monophyletic groups in our phylogeny. Although species with free siphon fronds, such as $R$. penicilloides or $R$. coppejansii, were mainly found in the first group, they also clustered with fan-shaped frond species ( $R$. sp1 and $R$. tomentosa). In our 
study, simple forms (with free siphons, and no or few and poorly developed tenacula) did not appear as ancestral characters, such as hypothesized by Womersley (1984) or Millar and Kraft (2001). We observed that species with simple morphologies appear independently throughout the Rhipileae lineage, instead of forming a single clade. This observation is the same as for the evolution of the morpho-anatomical characters of the tribe Udoteae, which does not follow a "from simple to complex" scenario; rather, complex character states have been estimated at the family's ancestral node and then, complex and simple morphologies are found at random in the various lineages of the tribe (see Lagourgue and Payri, 2020). Other similar evolutionary examples are known in macroalgae, including several life history traits in brown algae that do not follow a simple to complex scenario (e.g., heteromorphy/isomorphy, numbers of plastids, fertilization, growth or the macrocospic thallus architecture in brown algae crown radiation (BACR) orders (Silberfeld et al., 2010; Bringloe et al., 2020)), or the current uni- and multicellularity representations among the Ulvophyceae (Del Cortona et al., 2019).

Species in group 2 (Rhipilia and Rhipiliopsis-like species) also require taxonomic revision as the type species for both Rhipilia and Rhipiliopsis belong to other clades (Fig. 1 and 2). We propose the new genus Kraftalia gen. nov. to accommodate the nine species of group 2. Our results also confirmed that Rhipiliella should be included in tribe Rhipileae as proposed by Dragastan et al. (1997; as family Rhipiliaceae). Finally, we maintain the taxonomic status of the monospecific genera Rhipiliella and Johnson-sea-linkia.

Phylogeny of the "Rhipiliopsideae" lineages: Our phylogenetic reconstructions of the Rhipiliopsideae lineages (from the multilocus matrix including one specimen per species; dataset \#3 cf. Table S3) produced two well-supported non-sister clades (bs: 100; PP: 1, Figure 2) containing both Rhipiliopsis-like species. "Rhipiliopsideae group 1” was further subdivided 
into two moderately to strongly supported subclades, one representing Callipsygma (bs: 83; PP: 0.97) and the other one clustering seven Rhipiliopsis-like species (bs: 100; PP: 1).

“Rhipiliopsideae group 2” formed a well-supported clade sister to Halimeda (bs: 72; PP: 0.9) and contained nine Rhipiliopsis-like species, including the Rhipiliopsis type species (Figure 2).

Considering the polyphyly of Rhipiliopsis, we propose the following taxonomic solutions: (i) to redefine Rhipiliopsis and include only species clustering with its type-species, Rhipiliopsis peltata (i.e., "Rhipiliopsideae group 2”); and (ii) to describe Rhipiliospina gen. nov., to accommodate the Rhipiliopsis-like species of "Rhipiliopsideae group 1”.

We also considered two options to solve the polyphyly of the Rhipiliopsideae lineages: (i) maintain the tribe for its type genus, Rhipiliopsis, and describe a new tribe to accommodate species of "Rhipiliopsideae group 1” (i.e., Callipsygma and Rhipiliospina); or (ii) merge all three genera into the monogeneric tribe Halimedeae. For the time being, we believe the genera should remain in tribe Rhipiliopsideae until more data is collected and more reliable node supports are obtained to demonstrate whether the tribe is monophyletic and taxonomically valid or polyphyletic and requires taxonomic revision.

It is interesting to note that here again, genera with complex morpho-anatomy, such as Halimeda or Udotea, are phylogenetically more related to genera with much simpler and more delicate forms, such as Callipsygma or Chlorodesmis, than to each other. The morphological contrast between closely related taxa appears as a recurrent phylogenetic pattern in the suborder Halimedineae (cf. Fig. S1 and examples given above).

\section{Systematic revision and diversity of the various genera}


The diversity and the necessary taxonomic revisions of the various Rhipileae and Rhipiliopsideae genera included in this study (existing, revised, and new ones) are discussed below based on molecular, morphological, and phylogenic results.

Rhipilia (tribe Rhipileae): Our multilocus phylogeny (several representatives per species; dataset \# 4 cf. Table S3) indicated that Rhipilia should be revised to include seven species only (and not 12 as currently recorded in Guiry and Guiry, 2020) (Figure 3). Three of them are currently accepted species: $R$. tomentosa (the type species), $R$. penicilloides, and $R$. coppejansii, to which we add $R$. diaphana (resurrected here), and three other undescribed species, $R$. sp1, $R$. sp2, and $R$. sp3 (Figure 3). The resolution of ambiguous species hypotheses in the delimitation analyses, and the morphological verification of some GenBank specimens, could reveal additional species. For instance, GenBank sequences identified as $R$. nigrescens and $R$. orientalis clustered with our specimens of $R$. diaphana (Figures 3, S2 and S3). Additional genetic data and careful morphological analyses could help to make the correct taxonomic decision regarding these specimens.

Rhipilia diaphana is currently regarded a synonym of $R$. orientalis (Millar and Kraft, 2001), but both species appear genetically distinct. The latter was confirmed from specimens collected in Papua New-Guinea, which fully matched the original diagnosis (Gepp and Gepp, 1911; type locality: Fau Island, Eastern Indonesia). Rhipilia diaphana was also identified in our collection, among specimens from the Solomon Islands and Fiji, particularly from deep habitats (60 and $70 \mathrm{~m}$ ), which are similar to those of the type locality (Bikini Island, Marshall Is., samples dredged from 50 m). Specimens also morphologically matched the diagnosis of Taylor (1950). We thus propose to resurrect $R$. diaphana. The latter can be distinguished from $R$. orientalis by its longer stipe, broader and thinner blades and its soft green color (Taylor, 1950). Rhipilia orientalis is generally smaller in size, with a thicker 
blade, darker in color, and blackens as it dries (Taylor, 1950). We also found that the two species are anatomically distinguished by numerous tenacula and the presence of basal constrictions in $R$. diaphana, whereas tenacula are rare and not constricted in $R$. orientalis. Although Rhipilia includes species with widely diverging morphologies, its species have several characters in common, including the presence of a stolon (although $R$. tomentosa has been observed without stolon), dichotomies with a subdichotomous bulge and supradichotomous constrictions, and simple tenacula (2-3 prongs, up to four in $R$. sp1). Rhipilia has a pantropical distribution extending from the Indo-Pacific to the northwestern Atlantic (Caribbean). In our study, none of the species was present in all three oceans. Most species appeared restricted to small geographical areas, such as $R$. $\mathrm{sp} 1$ or $R$. sp3, which were collected only in the southwest Pacific, whereas $R$. coppejansii was found throughout the Indo-Pacific. Rhipilia tomentosa, described from the Caribbean (Antigua), was found only at this locality during our study. Records from the Pacific (e.g., Carolina Islands (Tsuda, 1972), Australia (Millar and Kraft, 2001), the Philippines (Ang et al., 2014)) and in the Indian Ocean (Seychelles (Titlyanova et al., 1992)), which are based on morphological observations only, should be confirmed with DNA sequences. Indeed, we assigned several of our specimens from the Chesterfield Islands to $R$. tomentosa based on the morphological description of specimens from Australia by Millar and Kraft (2001). However, our DNA analyses revealed that they actually belong to the new genus Kraftalia, and that $R$. tomentosa is probably restricted to the Atlantic. Any record of $R$. tomentosa from outside this region is a possible misidentification. Overall, in the absence of combined DNA analysis and in-depth morphoanatomical observations, Rhipilia species can be easily confused, which could partly explain overestimated geographical ranges. 
The new genus Kraftalia (tribe Rhipileae): The results of our phylogeny (Fig. 1; from dataset \#2) indicated the need to describe a new genus for nine Rhipilia and Rhipiliopsis-like species clustering in a strongly supported subclade of tribe Rhipileae (bs: 99; PP: 1, Fig. 1). Kraftalia gen. nov is proposed to accommodate the four species Rhipilia orientalis, Rhipilia crassa, Rhipiliopsis yaeyamensis, and Rhipiliopsis gracilis, as well as five other undescribed species. Kraftalia is characterized by a fan-shaped frond, the absence of stolon, relatively thin siphon diameters $(<100 \mu \mathrm{m})$, and the cohesion of siphons by one or more particular types of structures (direct longitudinal contact, papillae, differentiated siphons or tenacula).

Kraftalia is found in the Indo-Pacific with species restricted to specific geographical areas (Western Indian Ocean, West Pacific) (Figure 4). Only K. crassa occurs both in the Indian Ocean and the West Pacific. In our study, K. orientalis was collected only in the Indian Ocean and the Coral Triangle. There is no specimen from the Pacific or Atlantic oceans corresponding to this species, which raises questions about published records (Guiry and Guiry, 2020; as “Rhipilia orientalis”). For example, records of K. orientalis in southern Japan (Itono, 1986; as Rhipilia orientalis) could be Rhipilia diaphana, which is morphologically very similar and has a predominantly Pacific distribution. Again, verification is needed for GenBank sequences to confirm the correct geographical distribution of these species.

Rhipiliella (tribe Rhipileae): Our study provides the first genetic record of the monospecific Rhipiliella, containing only R. verticillata. Our species delimitation analyses, however, indicated that there is possibly more than one species, although these species hypotheses require confirmation with additional specimens from a more extensive geographical range. Rhipiliella is monophyletic and well-supported (bs: 100: PP: 1; Figure S7; from dataset \#5). Rhipiliella is morphologically distinct from other related genera by the presence of scars from deciduous blades along the monosiphonous stipe, its monostromatic blade, and the presence 
of papillae (Kraft, 1986). The specimens in our collection come from two different localities in New Caledonia (Grande Terre and Surprise Is.), which is not far from the type locality on the Australian Great Barrier Reef (Wistari Reef). It also perfectly matched the original diagnosis (Kraft, 1986). To date, the geographical distribution of Rhipiliella is restricted to the southwestern Pacific (Figure S7).

Other Rhipileae species: Additional species are clustering in tribe Rhipileae but their phylogenetic positions are not well supported and/or species richness is not enough documented to proceed with taxonomic revisions (e.g., species such as Pseudochlorodesmis sp. or Boodleopsis sp. were not included) (Figure 1). Indeed, some species are represented by only one or a few specimens ( $R$. profunda or $R$. pusilla), or by specimens from a single geographical area (New Caledonia for Rhipiliella and $R$. cf. mortensenii).

Rhipilia pusilla is one of them. It is sister to Johnson-sea-linkia profunda (Figures 1 and S7). Rhipilia pusilla is distinguished by a frond with free siphons, anisomorphic dichotomies and rare tenacula (Ducker, 1967; Womersley, 1984), while J. profunda is characterized by intersecting (“criss-cross”) siphons visible on the blade, and does not have scars left by deciduous blades along the stipe (Eiseman and Earle, 1983). In the absence of stronger phylogenetic support, and because of the limited morphological similarities to justify the grouping of these two species, we prefer to maintain the genus Johnson-sea-linkia and leave the status of $R$. pusilla in question.

The last Rhipileae species that branches separately is "Rhipiliopsis" cf. mortensenii (Figures 1 and S7). It is interesting to note that $R$. mortensenii was the type species of the genus Geppella (family Codiaceae) before the genus became a synonym of Rhipiliopsis. Here, the position of the species outside Rhipiliopsis raises the question of the resurrection of the genus Geppella (although the other ex-Geppella species do not cluster with 
$R$. mortensenii). However, the weak node supports and lack of genetic data to correctly assess the species richness of the possible genus prevented us from reliably concluding about its taxonomic status.

These three species are geographically restricted. Johnson-sea-linkia profunda is only found in the Caribbean, R. pusilla in Southern Australia, and R. cf. mortensenii in New Caledonia and surrounding islands (Figure S7). Additional phylogenetic analyses on geographically larger datasets are needed to resolve the phylogenetic relationships within this set of species.

Rhipiliopsis (tribe Rhipiliopsideae): “Rhipiliopsideae group 2” corresponds to Rhipiliopsis sensu stricto (Figure 2; N.B.: although the position of the type species, $R$. peltata, is not the same in all trees (Fig. 2 and 5), maybe due to differences in sample size, it still represents “Rhipiliopsideae group2”). The results of our species delimitation analyses (Figure 5; dataset \#6) indicate that the revised genus consists of nine species. They include $R$. peltata (the typespecies), $R$ corticata, $R$. reticulata, $R$. papuensis, and five additional species, which have yet to be described: $R$. sp5, $R$. sp6, $R$. sp7, $R$. sp8, and $R$ sp9.

Based on our data, the genus Rhipiliopsis s.s. is characterized by the following: a strongly corticated stipe (ascending siphons or protuberances), supra-dichotomous constrictions and two types of adhesions between the siphons, i.e., papillae of type I (bilateral contact in $\mathrm{H}$ structure) or II (unilateral). Interestingly, morphologically similar species can occur in very distant localities, e.g., $R$. corticata from New Caledonia and $R$. sp5 from Madagascar; or $R$. reticulata from the Caribbean and its sister species $R$. sp7 from Madagascar (Figure 5). According to our distribution map (Figure 5), each species of Rhipiliopsis s.s. is restricted geographically. Still, the genus has a cosmopolitan distribution, with $R$. reticulata occurring 
591

592 five in the West Pacific).

593

However, our dataset for this group is relatively limited (e.g., only one sequence for some

594 species and limited node support for others), and a more comprehensive sampling is needed to better document species diversity, phylogenetic relationships, and geographical distribution.

The new genus Rhipiliospina (tribe Rhipiliopsideae): We propose Rhipiliospina gen. nov. to accommodate Rhipiliopsis-like species clustering in clade "Rhipiliopsideae group 1” (bs: 100; New-Guinea (Figure 6).

species (Figure 6; dataset \#7). Six require formal description (the type species, $R$. stellifera sp. nov. is described in Taxonomic Treatment section), and one requires further investigation ( $R$. sp5 cf. Rhipiliopsis echinocaulos). Each species is strongly supported (bs>98; PP: 1) except Rhipiliospina sp4 (bs: 89; PP: 1).

Rhipiliospina gen. nov. is characterized by a monosiphonous and corticated stipe with very remarkable spines (hence the genus name), which are simple or forked. Besides, all species have broad dichotomies without subdichotomous bulge, but with marked supra-dichotomous constrictions. Siphons adhere to each other by papillae of type I (bilateral contact in $\mathrm{H}$ structure) or II (unilateral).

Based on our data, the genus has a strict Indo-Pacific distribution. In this study, we found that these species have geographically restricted ranges and could be endemic to them. For instance, $R$. sp2 has only been collected from the Isle of Pines in New Caledonia, and $R$. sp6 is so far only known from the Chesterfield and Surprise islands in New Caledonia.

Rhipiliospina sp1 has the widest distribution and is found both in southern Japan and Papua 
The genus Callipsygma (tribe Rhipiliopsideae): Callipsygma is currently known as a monospecific genus and is reported only from Australia. In our analyses, specimens of the genus Callipsygma formed a well-supported clade (bs: 92; PP: 1, Fig. 6) branching as a sister lineage to the new genus Rhipiliospina. The results of our species delimitation analyses indicate that it consists of two species, including the type-species Callipsygma wilsonis and a new species, Callipsygma brevis sp. nov. (Figure 6).

The genus Callipsygma is characterized by an upper vegetative part composed of free siphons adhering together by lateral ramifications (Gepp and Gepp, 1911). The two species $C$. wilsonis and C. brevis can be distinguished from each other by the smaller size of thallus and stipe length in C. brevis and the diameter of their siphons, which is more than twice as large in the type species. They also have distinct geographical distributions, with the type species known only from Australia and the new species so far being collected only from northern Madagascar. The addition of the latter to Callipsygma thus extends the geographical distribution of the genus to the Western Indian Ocean (Figure 6).

\section{Using different tools to better understand taxonomy and diversity}

Our integrative taxonomic approach used a combination of tools to explore the diversity, phylogeny and systematics of the tribes Rhipileae and Rhipiliopsideae. They included species delimitation methods, based on genetic data, and morpho-anatomical observations. The species delimitation approach was used as a first step in a comprehensive integrative taxonomy approach to map species diversity (and not only genetic diversity) and resolve taxonomic ambiguities. The phylogenetic approach was also used to study and assess the diversity of the different genera and their evolutionary relationships within the two tribes. Our results underline the systematic value of morpho-anatomical characters in an integrative taxonomy approach, as already pointed out by several authors (Cianciola et al., 2010; Vieira 
et al., 2014, Lagourgue et al., 2018) and the importance of combining morphological and genetic data. Without proper molecular-based species delimitation analyses, some of the species would not have been distinguished using morphological analyses alone. Similarly, without morpho-anatomical observations, most of the SSHs defined by the species delimitation analyses could not have been assigned to correct species due to the lack of available valid genetic data for most species (e.g., Rhipilia diaphana). Also, a number of species hypotheses would not have been verified and confirmed. In phycology, most taxonomic studies are based on morphology resulting in an inestimable amount of information. The morphological characters recorded in the literature are critical to identify species, but their relevance and diagnostic robustness need to be verified, particularly in the context of taxonomic revision. The combination of morphological and molecular approaches has proven relevant, if not essential, to assess specific diversity accurately and provide correct species identifications.

It is by combining all these complementary and relevant tools and methods that we have been able to provide a significant taxonomic update about the diversity and phylogenetic relationships among members of tribes Rhipileae and Rhipiliopsideae.

\section{TAXONOMIC TREATMENT}

Rhipilia Kützing emend.

Description emended from Kützing (1858) and Gepp and Gepp (1911): Thallus uncalcified, green, stipitate or subsessile, with a stolon, and with a frond of variable form, flabellate, cuneate, peltate, infundibuliform or composed of free siphons, sometimes zonate. Siphons cylindrical, straight, bent or tortuous, 20-320 $\mu \mathrm{m}$ in diameter, very laxly interwoven and dichotomously branched. Dichotomies have a subdichotomous bulge and supra-dichotomous 
constrictions, with often a cell-wall thickening. Blade siphons (sometimes only basal siphons) have at least one of the four types of adhesion structures: 1) tenacula with 2-3(4) prongs, often with basal constrictions; 2) discoid tenacula; 3) hook-shaped tenacula; 4) differentiated bent siphons apices.

Distribution (confirmed by DNA sequences): Atlantic Ocean: Mexico (Lam and Zechman, 2006); Indian Ocean: Madagascar (This study), Mayotte (This study), Western Australia (Scott Reef) (Verbruggen et al., 2009; Verbruggen and Schils, 2012); Pacific Ocean: New Caledonia (Chesterfield Is., Surprise Is., Grande Terre) (This study), Fiji (This study), Guam (Verbruggen and Schils, 2012), Papua New-Guinea (This study), Solomon Is. (This study), Australia (Queensland: Heron Is.; Masthead Is.) (Verbruggen and Schils, 2012); Tuvalu (This study); Southwestern Asia: Philippines (Verbruggen et al., 2009).

Type species: R. tomentosa Kützing; Type locality: Antigua, Antilles, West Indies; Lectotype: MEL 14088 (and 13 isolectotype specimens).

List of other species (confirmed by DNA sequences in this study): R. penicilloides, $R$. coppejansii, $R$. diaphana, and three undescribed species.

We also propose the resurrection of:

Rhipilia diaphana W.R.Taylor 1950: 72, 205, pl. 37

Type locality: Bikini Atoll, Marshall Is.

Type: Holotype: Taylor, 13.iv.1946, MICH 1306664 (=WRT 46-195), dredged from 57 m. Description emended from Taylor (1950): Uncalcified thalli, composed of a creeping stolon, a simple or compound stipe, from which arise a flabellate frond. The frond is large, thin and diaphanous, green in color, and zonate. Siphons are visible at the surface, they are tortuous, subparallel, rarely interwoven, 30-55 $\mu \mathrm{m}$ (up to 50-60 $\mu \mathrm{m}$ ) in diameter; Siphons are dichotomously divided with isomorphic and lax dichotomies, subdichotomous bulges, and 
691

692

693

694

695

696

697

698

699

700

701

702

703

704

705

706

707

708

709

710

711

712

713

714

715

symmetrical supra-dichotomous constrictions with cell-wall thickening. Siphons have many adhesion structures that are found all along the blade, and which correspond either to twopronged tenacula (150-300 $\mu \mathrm{m}$ long) with basal constriction or spines.

Distribution (confirmed by DNA sequences in this study*): Pacific Ocean: Fiji*, Solomon Is. ${ }^{*}$, Marshall Is. (type locality, no DNA data).

List of vouchers (limited to two per locality): Fiji, 2007: NOU 204022, NOU 204069;

Solomon Is., 2006: NOU 087399, NOU 087400

\section{Kraftalia Lagourgue \& Payri gen. nov., Figure 7.}

Type species: Kraftalia orientalis (A. Gepp and E.S. Gepp) Lagourgue and Payri comb. nov.; Basionym: Rhipilia orientalis A. Gepp and E.S. Gepp 1911: 57, 140, pl. XVI: figs. 134-136

Description: Uncalcified thalli, anchor system (no stolon), a corticated or uncorticated stalk, which can be mono or multisiphonous, and a fan-shaped blade, which can be mono or pluristromatic. Siphons are dichotomously divided with or without supra-dichotomous constrictions. Siphons diameter are $<100 \mu \mathrm{m}$. Cohesion between siphons is due to one or several types of adhesion structures (direct longitudinal contact, differentiated siphons, papillae or tenacula).

Etymology: The name honors Dr. Gerald T. Kraft, who described three of the nine species included in the genus.

Distribution (confirmed by DNA sequences*): Indian Ocean: Madagascar* (This study), Juan de Nova* (This study), Western Australia* (Scott Reef) (Verbruggen et al. 2009), Mayotte* (This study); Southwestern Asia: Indonesia (Bunaken*) (This study), Philippines* (Verbruggen et al., 2009); Pacific Ocean: Australia (Heron Is.)(type locality, no DNA data), Papua New-Guinea* (This study), Tuvalu* (This study), Fiji (This study), New Caledonia* (Chesterfield Is., Surprise Is., Grande Terre) (This study), Japan* (Sauvage et al., 2016). 
Species included in the genus (confirmed by molecular data in this study): Kraftalia orientalis, K. crassa, K. gracilis, K. yaeyamensis, and five undescribed species.

We propose the following new combinations for the transfer of selected Rhipilia species to the new genus Kraftalia:

Kraftalia orientalis (A. Gepp and E.S. Gepp) Lagourgue \& Payri comb. nov.

Basionym: Rhipilia orientalis A. Gepp and E.S. Gepp 1911: 57, 140, pl. XVI: figs. 134-136 Syntypes localities: Fau Island, Malay Archipelago; Pulu Sebangkatan, Borneo Bank Type: n³34; L 3997222 (holotype); fig. 134a of Gepp and Gepp 1911, ex L 937, 279...308 = MELU A235, and MICH 21873 (lectotypes); MICH 23026 (isotype)

Description emended from Gepp and Gepp (1911) and Millar and Kraft (2001), see also Fig. $7 A, 7 F$, and $7 K$ : Plants uncalcified, brownish-green to yellow-green (blackening when dried), small (6-10 cm in length), without stolon, stipitate with simple or compound narrow and short stipes (up to $1 \mathrm{~cm}$ long, $0.1-0.2 \mathrm{~cm}$ thick), expanding above into the frond. Frond flabelliform to infundibuliform or peltate, small and thick (mostly $1-3$ (up to $6 \mathrm{~cm}$ ) cm-long, 1-2.5 (rarely 4) cm-wide), soft and finely meshed, almost like brown-stained muslin, not or rarely zonate and with rounded to lacerate margins. Frond siphons (22-) 30-36 (-55) $\mu \mathrm{m}$ in diameter, straight or slightly bent, interwoven, with a recurved, rounded or swollen apex. Siphons are dichotomously divided with asymmetrical supra-dichotomous constrictions and slight cell-wall thickening. Cohesion between siphons are due to either (i) simple, short and stubby pronged-tenacula (2-3 prongs, variable in length: (70) 170-500 $\mu \mathrm{m}$-long) without basal constriction; (ii) hook-shaped tenacula without basal constriction; or (iii) differentiated siphons (adhesion by rounded apex). Adhesion structures are rare. 
Distribution (confirmed by DNA sequences in this study*): South-east Asia: Indonesia

740 (Borneo Bank, Fau Is.) (type locality, no DNA data); Indian Ocean: Mayotte* (this study);

741 Pacific Ocean: Papua New-Guinea* (this study).

742

743

744

745

746

747

748

749

750

751

752

753

754

755

756

757

758

759 Kraftalia gracilis (Kraft) Lagourgue \& Payri comb. nov.

760 Basionym: Rhipiliopsis gracilis Kraft 1986: 55, figs 17-21

761 Type locality: Heron Island, Capricorn Group, Great Barrier Reef, Australia

762

763

List of vouchers (limited to two per locality): Mayotte, 2010: NOU 204163, NOU 204170;

2016: NOU 203544, NOU 203569; Papua New-Guinea, Madang, 2012: NOU 203532, NOU

204123; Papua New-Guinea, Kavieng, 2014: NOU 203350, NOU 203353

Kraftalia crassa (A.J.K. Millar and Kraft) Lagourgue \& Payri comb. nov

Basionym: Rhipilia crassa A.J.K. Millar and Kraft 2001: 32, figs 37-40, 53-58

Type locality: Heron Island, Capricorn Group, Great Barrier Reef, Australia

Type: MELU A37571 (holotype); MELU A35070 and A37569-74 (isotypes).

Description: see Millar and Kraft (2001; see also Fig. 7B, 7G, and 7L

Distribution (confirmed by DNA sequences*): Indian Ocean: Madagascar* (This study), Juan

de Nova* (This study), Western Australia* (Scott Reef) (Verbruggen et al. 2009);

Southwestern Asia: Indonesia* (Bunaken) (this study), Philippines* (Verbruggen et al.,

2009); Pacific Ocean: Japan* (Sauvage et al., 2016); Australia (Heron Island) (type locality, no DNA data).

List of vouchers (limited to two per locality): Madagascar, 2016: NOU 203728, NOU 203731;

Juan de Nova, 2013: NOU 204191; Indonesia, Bunaken, 2014: NOU 203475, NOU 203483.

Type: MELU K16136 (holotype); MELU KI5568 and MELU KI6161 (isotypes).

Description: see Kraft (1986); see also Fig. 7C, 7H, and 7M. 
Distribution (confirmed by DNA sequences*): Pacific Ocean: New Caledonia* (Chesterfield, Grande Terre, Surprises Is.) (This study); Australia (Heron Is.) (type locality, no DNA data) List of vouchers (limited to two per locality): New Caledonia, Chesterfield, 2015: NOU 203281, NOU 203320; New Caledonia, Grande Terre, 2017: NOU 203756, NOU 203866;

New Caledonia, Surprise Is., 2017: NOU 203949, NOU 203963.

Kraftalia yaeyamensis (Tanaka) Lagourgue \& Payri comb. nov.

Basionym: Geppella yaeyamensis, Tanaka 1963: 65, figs 2, 3

Type locality: Iriomotejima, Funauke, Ryukyu Island, Japan

Type: T. Tanaka, 2.xi.1959, 20m deep (holotype)

Synonym: Rhipiliopsis yaeyamensis (Tanaka) Kraft 1986: 71

Description: see Tanaka (1963) and Kraft (1986); see also Fig. 7D, 7I, and 7N.

Distribution (confirmed by DNA sequences*): Pacific Ocean: New Caledonia* (Grande Terre, Surprises); Japan (type locality, no DNA data)

List of Vouchers (limited to two per locality): New Caledonia, Grande Terre, 2017: NOU 203750, NOU 203762; New Caledonia, Isle of Pines, 2013: NOU 203405, NOU 203406;

New Caledonia, Surprise Is., 2017: NOU 203903, NOU 203915.

Rhipiliopsis s.s. A. Gepp and E.S. Gepp 1911: 57, 140, pl. XVI: figs. 134-136

Description: see Gepp and Gepp (1911).

Distribution (confirmed by DNA sequences*): Atlantic: Antilles (type locality, no DNA data); Panama* (Kooistra, 2002); Indian Ocean: Maldives Is.* (This study), Madagascar* (This study); Pacific Ocean: Australia* (Victoria) (Cremen et al., 2019); Lord Howe Is. (type locality, no DNA data); New Caledonia* (Chesterfield, Grande Terre, Surprise Is.) (This study), Papua New-Guinea* (This study). 
Type species: R. peltata (J. Agardh) A. Gepp and E.S. Gepp

Type: Agardh, LD 15800 (BM)

Type locality: Port Phillip Heads, Victoria, Australia

Basionym: Udotea peltata J. Agardh.

Other species included in the genus (as a result of the present study): Rhipiliopsis corticata, R. reticulata, $R$. papuensis, and five undescribed species.

\section{Rhipiliospina Lagourgue \& Payri gen. nov.}

Type species: Rhipiliospina stellifera Lagourgue \& Payri sp. nov.

Description: Uncalcified thalli composed of a monosiphonous and corticated stipe with very remarkable spines, simple or forked, and a flabelliform or cyathiform frond, mono or pluristromatic. Siphons dichotomously divided and $<50 \mu \mathrm{m}$ in diameter. Broad dichotomies, with deep supra-dichotomous constrictions. Adhesion of the siphons by papillae of type I (bilateral contact in H structure) or II (unilateral).

Etymology: The name refers to its resemblance to the genus Rhipiliopsis and the presence of remarkable spines on the stipe.

Distribution (confirmed by DNA sequences): Indian Ocean: Madagascar (This study); Pacific Ocean: New Caledonia (Iles of Pines, Chesterfield, Grande Terre, Surprise Is.) (This study), Papua New-Guinea (Madang) (This study); Japan (Sauvage et al., 2016; as Rhipiliaceae sp.) List of species: Rhipiliospina stellifera and six undescribed species.

\section{Rhipiliospina stellifera Lagourgue \& Payri sp. nov., Figure 8}

Holotype: NOU203095

Type locality: Ouen Islet, Canal Woodin, New Caledonia. 
Description: Uncalcified thalli composed of a monosiphonous and corticated stipe (150 $\mu \mathrm{m}$ in diameter), with forked and complex spines, including star-shaped spines, and a pluristromatic rounded and flabelliform frond that is also thin and zonate. Siphons dichotomously divided, tortuous, $10-30 \mu \mathrm{m}$ in diameter, entangled in a disorganized network. Broad dichotomies with a square or trapezoid shape, and symmetrical supra-dichotomous constrictions, with or without cell-wall thickening. Siphon adhesion is provided by numerous and proximate papillae of type I (bilateral contact in H structure) or II (unilateral) with a ring of cell-wall in the contact zone. Papillae also adhere to siphons in different layers, giving a "3D" cortication aspect.

Etymology: The name refers to the star-shaped spines on the stipe.

Distribution confirmed by molecular data: Pacific Ocean: New Caledonia (This study).

List of vouchers and representative species sequences: New Caledonia, Western lagoon, Voh, 2017: NOU 203758 (tufA: MT782677, rbcL: MT783058; 18S: MT782551); NOU 203761 (tufA: MT782798; rbcL: MT783164; 18S: MT782606); NOU 203764 (tufA: MT782722; rbcL: MT783101); New Caledonia, Southern Lagoon, Ouen Isle, 2015: NOU 203095 (tufA: MT782684; rbcL: MT783065; 18S: MT782553), NOU 203096 (tufA: MT782673).

\section{Callipsygma brevis Lagourgue \& Payri sp. nov., Figure 9}

Holotype: NOU203608

Type locality: Madagascar, South, Diego Suarez Bay

Description: Uncalcified thalli, green, with a multisiphonous stipe and a tufted frond composed of free siphons weakly adhering to each other by lateral ramifications, which form a cohesive, feather-like whole. Stipe siphons with protuberances and deformed lateral branches. Frond siphons lightly tortuous, thin, 50-70 um in diameter, dichotomously divided, and with rounded apices. Dichotomies $\left(45^{\circ}\right)$ with subdichotomous bulges and symmetrical 
838 constrictions above, with a ring of cell-wall thickening almost occlusive; Adhesion between

839 siphons with a few circular, uni- or bilateral papillae.

840 Etymology: In reference to the size of the stipe and thallus, which are shorter than the type

841 species (C. wilsonis).

842 List of vouchers and representative species sequences: Madagascar, South, Diego Suarez

843 Bay, 2016: NOU 203608 (tufA: MT782750; rbcL: MT783124); NOU 203609 (tufA:

844 MT782810; rbcL: MT783174). 


\section{ACKNOWLEDGMENTS}

This work was supported by the DUNE Labex-CORAIL and ENTROPIE funds. The authors are grateful to Heroen Verbruggen and Chiela Cremen for providing additional sequences. Many thanks to Francesca Benzoni for her help with latin names, and Lydiane Mattio for her critical review of the manuscript. The English language has been verified by blue[c]weed. Samples have been collected during several campaigns: Guadeloupe, 2014, Onema and MNHN fieldtrip; Lesser Antilles, 2015: R/V ANTEA, Pacotilles, doi; Bunaken, 2014 : INDESO project (research permit 133/SIP/FRP/SM/V/2015 and 918/BLITBANKKP/II/2016); Fiji, 2007: R/V Alis, BSM-Fidji, doi; Papua New-Guinea, Madang, 2012: NUIGUINI campaign, doi; Papua New-Guinea, Kavieng, 2014: doi; Madagascar, 2016: R/V Antea, MAD, doi; Maldives Islands, 2009 : « Programme Maldives 2009 »; Mayotte, 2010 : TARA; 2016: SIREME; New Caledonia, 2005 : BSM-LOYAUTE, doi; 2008 : CORALCAL2, doi; 2012: CORALCAL4, doi; Iles of Pines and Surprises Islands, 2013, LOF ; Iles of Pines and Chesterfield Islands, 2015: R/V ALIS, CHEST, doi; Grande Terre, and Surprises Islands, 2017: R/V ALIS PostBlanco1 and TARA-NC ; Scattered Islands, Glorioso Is., 2012 and Juan de Nova, 2013: BIORECIE; Solomon Islands, 2004: R/V ALIS, BSM-Salomon; Tuvalu, 2014: “Programme SARGASSES”. No conflict of interest. 
865

866

867

868

869

870

871

872

873

874

875

876

877

878

879

880

881

882

883

884

885

886

887

888

\section{REFERENCES}

Ang, P. O., Leung, S. M. \& Choi, M. M. 2014. A verification of reports of marine algal species from the Philippines. Philipp. J. Sci. 142:5-49.

Bond, J. E. \& Stockman, A. K. 2008. An integrative method for delimiting cohesion species:

Finding the population-species interface in a group of Californian trapdoor spiders with extreme genetic divergence and geographic structuring. Syst. Biol. 57:628-46.

Bringloe, T. T., Starko, S., Wade, R. M., Vieira, C., Kawai, H., De Clerck, O., Cock, J. M., Coelho, S. M., Destombe, C., Valero, M., Neiva, J., Pearson, G. A., Faugeron, S., Serrão, E. A. \& Verbruggen, H. 2020. Phylogeny and evolution of the brown algae. Crit. Rev. Plant Sci. 39:281-321.

Caragnano, A., Foetisch, A., Maneveldt, G. W., Millet, L., Liu, L. C., Lin, S. M., Rodondi, G., \& Payri, C. E. 2018. Revision of Corallinaceae (Corallinales, Rhodophyta): recognizing Dawsoniolithon gen. nov., Parvicellularium gen. nov. and Chamberlainoideae subfam. nov. containing Chamberlainium gen. nov. and Pneophyllum. J. Phycol. 54:391-409.

Carstens, B. C. \& Knowles, L. L. 2007. Estimating species phylogeny from gene-tree probabilities despite incomplete lineage sorting: An example from Melanoplus grasshoppers. Syst. Biol. 56:400-11.

Carstens, B. C., Pelletier, T. A., Reid, N. M. \& Satler, J.D. 2013. How to fail at species delimitation. Mol. Ecol. 22:4369-83.

Chesters, D. 2013. Collapsetypes.pl. Available at: https://sourceforge.net/projects/ collapsetypes (last accessed 23 March 2020).

Collins, R. A., \& Cruickshank, R. H. 2013. The seven deadly sins of DNA barcoding. Mol. Ecol. Resour. 13:969-75.

Coppejans, E., De Clerck, O. \& Leliaert, F. 1999. New records of the green-algal genus 
Rhipiliopsis (Udoteaceae, Caulerpales) from Papua New Guinea and the Seychelles Islands, including the description of Rhipiliopsis papuensis Coppejans, De Clerck \& Leliaert, sp. nov. Bot. Mar. 42:377-82.

Cremen, C. M., Huisman, J. M., Marcelino, V. R., \& Verbruggen, H. 2016. Taxonomic revision of Halimeda ( Bryopsidales, Chlorophyta ) in south-western Australia. Aust. Syst. Bot. 29:41-54.

Cremen, C. M., Leliaert, F., West, J., Lam, D. W., Shimada, S., Lopez-Bautista, J. M. \& Verbruggen, H. 2019. Reassessment of the classification of Bryopsidales (Chlorophyta) based on chloroplast phylogenomic analyses. Mol. Phylogenet. Evol. 130:397-405.

De Clerck, O., Guiry, M. D., Leliaert, F., Samyn, Y., \& Verbruggen, H. 2013. Algal Taxonomy: A Road to Nowhere? J. Phycol. 49:215-25.

Dragastan, O., Richter, D. K., Kube, B., Popa, M., Sarbu, A. \& Ciugulea, I. 1997. A new family of paleo-mesozoic calcareous green siphons-algae (Order Bryopsidales, Class Bryosidophyceae, Phylum Siphonophyta). Rev. Esp. Micropaleontol. 29:69-135.

Drummond, A. J., Suchard, M. A., Xie, D. \& Rambaut, A. 2012. Bayesian phylogenetics with BEAUti and the BEAST 1.7. Mol. Biol. Evol. 29:1969-73.

Ducker, S. 1967. The genus Chlorodesmis (Chlorophyta) in the Indo-Pacific region. Nov. Hedwigia 13:145-82.

Dupuis, J. R., Roe, A. D. \& Sperling, F. A. H. 2012. Multi-locus species delimitation in closely related animals and fungi: one marker is not enough. Mol. Ecol. 21:4422-36.

Eiseman, N. J. \& Earle, S. A. 1983. Johnson-sea-linkia profunda, a new genus and species of deep-water Chlorophyta from the Bahama Islands, Phycologia 22:1-6.

Farghaly, M. S. \& Denizot, M. 1979. A propos de trois especes nouvelles d’Udoteacees (Caulerpales, Chlorophycees) considerees comme appartenant au genre Rhipiliopsis . Rev. Algol. 14:71-72. 
Fujita, M. K., Leache, A. D., Burbrink, F. T., Mcguire, J. A. \& Moritz, C. 2012. Coalescentbased species delimitation in an integrative taxonomy. Trends Ecol. Evol. 27:480-8. Gepp, A. \& Gepp, E. S. 1911. The Codiaceae of the Siboga Expedition, including a monograph of Flabellarieae and Udoteaceae. Siboga-Expeditie 62:1-150.

Guiry, M. D. \& Guiry, G. M. 2020. AlgaeBase. World-wide electronic publication, National University of Ireland, Galway. http://www.algaebase.org (last accessed 20 January 2020) Händeler, K., Wägele, H., Wahrmund, U., Rüdinger, M. \& Knoop, V., 2010. Slugs’ last meals: molecular identification of sequestered chloroplasts from different algal origins in Sacoglossa (Opisthobranchia, Gastropoda). Mol. Ecol. Resour. 10:968-78.

Hotaling, S., Foley, M. E., Lawrence, N. M., Bocanegra, J., Blanco, M. B., Rasoloarison, R., Kappeler, P. M., Barrett, M. A., Yoder, A. D., \& Weisrock, D. W. 2016. Species discovery and validation in a cryptic radiation of endangered primates: coalescent-based species delimitation in Madagascar's mouse lemurs. Mol. Ecol. 25:2029-45.

Hughey, J. R., Maggs, C. A., Mineur, F., Jarvis, C., Miller, K. A., Shabaka, S. H., \& Gabrielson, P. W. (2019). Genetic analysis of the Linnaean Ulva lactuca (Ulvales, Chlorophyta) holotype and related type specimens reveals name misapplications, unexpected origins, and new synonymies. J. Phycol. 55: 503-8

Itono, H. 1986. New records of marine algae from southern parts of Japan. Japanese J. Phycol. 34:72-82.

Kapli, P., Lutteropp, S., Zhang, J., Kobert, K., Pavlidis, P., Stamatakis, A. \& Flouri, T. 2017. Multi-rate poisson tree processes for single-locus species delimitation under maximum likelihood and markov chain Monte Carlo. Bioinformatics 33:1630-8.

Kazi, M. A., Reddy, C. R. K., \& Jha, B. 2013. Molecular phylogeny and barcoding of Caulerpa (Bryopsidales) based on the tufA, $r b c \mathrm{~L}, 18 \mathrm{~S}$ rDNA and ITS rDNA genes. PLoS ONE 8:e82438. 
Kearse, M., Moir, R., Wilson, A., Stones-Havas, S., Cheung, M., Sturrock, S., Buxton, S., Cooper, A., Markowitz, S., Duran, C., Thierer, T., Ashton, B., Meintjes, P. \& Drummond, A. 2012. Geneious Basic: An integrated and extendable desktop software platform for the organization and analysis of sequence data. Bioinformatics 28:1647-49.

Kekkonen, M., \& Hebert, P. D. N. 2014. DNA barcode-based delineation of putative species: efficient start for taxonomic workflows. Mol. Ecol. Resour. 14:706-15.

Knowles, L. L., \& Carstens, B. C. 2007. Delimiting Species without Monophyletic Gene Trees. Syst. Biol. 56:887-95.

Kooistra, W. H. C. F. 2002. Molecular phylogenies of Udoteaceae (Bryopsidales, Chlorophyta) reveal nonmonophyly for Udotea, Penicillus and Chlorodesmis. Phycologia 41:453-62.

Kooistra, W. H. C. F., Coppejans, E. G. G., \& Payri, C. E. 2002. Molecular systematics, historical ecology, and phylogeography of Halimeda (Bryopsidales). Mol. Phylogenet. Evol. 24:121-38.

Kraft, G. T. 1986. The green algal genera Rhipiliopsis A. \& E.S. Gepp and Rhipiliella gen. nov. (Udoteaceae, Bryopsidales) in Australia and the Philippines. Phycologia 25:47-72. Kraft, G. T. 2000. Marine and estuarine benthic green algae (Chlorophyta) of Lord Howe Island, south-western Pacific. Aust. Syst. Bot. 13:509-648.

Kubatko, L. S., \& Degnan, J. H. 2007. Inconsistency of phylogenetic estimates from concatenated data under coalescence. Syst. Biol. 56:17-24.

Kützing, F. T. 1858. Tabulae phycologicae. oder, Abbildungen der Tange VIII, i-ii, 1-48 pp, 100 pls.

Lagourgue, L., Puillandre, N. \& Payri, C. E. 2018. Exploring the Udoteaceae diversity (Bryopsidales, Chlorophyta) in the Caribbean region based on molecular and morphological data. Mol. Phylogenet. Evol. 127:758-69. 
Lagourgue, L., Verbruggen, H., Ampou, E. E., \& Payri, C. E. 2020. One hundred years later, resurrection of Tydemania gardineri A. Gepp \& E. Gepp (Udoteaceae, Chlorophyta) based on molecular and morphological data. Eur. J. Phycol. 55:89-99.

Lagourgue, L. \& Payri, C. E. 2020: Large scale diversity reassessment, evolutionary history, and taxonomic revision of the green macroalgae family Udoteaceae (Bryopsidales,

Chlorophyta). J. Syst. Evol. 00:1-27.

Lam, D. W. \& Zechman, F. W. 2006. Phylogenetic analyses of the Bryopsidales

(Ulvophyceae, Chlorophyta) based on Rubisco large subunit gene sequences. J. Phycol. 42:669-78.

Leliaert, F., Verbruggen, H., Wysor, B., \& Clerck, O. De. 2009. DNA taxonomy in morphologically plastic taxa: Algorithmic species delimitation in the Boodlea complex (Chlorophyta: Cladophorales). Mol. Phylogenet. Evol. 53:122-33

Leliaert, F., Verbruggen, H., Vanormelingen, P., Steen, F., López-Bautista, J.M., Zuccarello, G. C. \& De Clerck, O. 2014. DNA-based species delimitation in algae. Eur. J. Phycol. 49: 179-96

Leliaert, F., Payo, D. A., Gurgel, C. F. D., Schils, T., Draisma, S. G. A., Saunders, G. W., Kamiya, M., Sherwood, A. R., Lin, S.-M., Huisman, J. M., Le Gall, L., Anderson, R. J., Bolton, J. J., Mattio, L., Zubia, M., Spokes, T., Vieira, C., Payri, C. E., Coppejans, E., ... De Clerck, O. 2018. Patterns and drivers of species diversity in the Indo-Pacific red seaweed Portieria. J. Biogeogr. 45:2299-313.

Luo, A., Ling, C., Ho, S. Y. W., Zhu, C. D., \& Mueller, R. 2018. Comparison of methods for molecular species delimitation across a range of speciation scenarios. Syst. Biol. 67:830-846.

Mason, V. C., Li, G., Minx, P., Schmitz, J., Churakov, G., Doronina, L., Melin, A. D., Dominy, N. J., Lim, N. T.-L., Springer, M. S., Wilson, R. K., Warren, W. C., Helgen, K. M., \& Murphy, W. J. 2016. Genomic analysis reveals hidden biodiversity within colugos, the 
sister group to primates. Science Advances 2:e1600633.

Millar, A. J. K. \& Kraft, G. T. 2001. Monograph of the green macroalgal genus Rhipilia (Udoteaceae, Halimedales), with a description of $R$. crassa sp. nov. from Australia and the Philippines. Phycologia 40:21-34.

Miller, M. A., Pfeiffer, W. \& Schwartz, T. 2010. Creating the CIPRES Science Gateway for inference of large phylogenetic trees, in: 2010 Gateway Computing Environments Workshop (GCE). IEEE, 1-8.

Monaghan, M. T., Wild, R., Elliot, M., Fujisawa, T., Balke, M., Inward, D. J. G., Lees, D. C., Ranaivosolo, R., Eggleton, P., Barraclough, T. G. \& Vogler, A. P. 2009. Accelerated species inventory on Madagascar using coalescent-based models of species delineation. Syst. Biol. 58:298-311.

Montecinos, A. E., Couceiro, L., Peters, A. F., Desrut, A., Valero, M., \& Guillemin, M. L. 2017. Species delimitation and phylogeographic analyses in the Ectocarpus subgroup siliculosi (Ectocarpales, Phaeophyceae). J. Phycol., 53:17-31.

N’Yeurt, A. D. R. \& Keats, D. W. 1997. Rhipilia penicilloides sp. nov. (Udoteaceae, Chlorophyta) from Fiji. Phycologia 36:172-8.

Norris, J. N. \& Olsen, J. L. 1991. Deep-watter green algae from the Bahamas, including Cladophora Vandenhoekii sp.nov (Cladophorales). Phycologia 30:315-28.

Payri, C. E., \& Verbruggen, H. 2009. Pseudocodium mucronatum, a new species from New Caledonia, and an analysis of the evolution of climatic preferences in the genus (Bryopsidales, Chlorophyta). J. Phycol. 45:953-61.

Pons, J., Barraclough, T. G., Gomez-zurita, J., Cardoso, A., Duran, D. P., Hazell, S., Kamoun, S., Sumlin, W. D. \& Vogler, A. P. 2006. Sequence-Based Species Delimitation for the DNA Taxonomy of Undescribed Insects. Syst. Biol 55:595-609.

Puillandre, N., Lambert, A., Brouillet, S. \& Achaz, G. 2012a. ABGD, Automatic Barcode 
1014

1015

1016

1017

1018

1019

1020

1021

1022

1023

1024

1025

1026

1027

1028

1029

1030

1031

1032

1033

1034

1035

1036

1037

1038

Gap Discovery for primary species delimitation. Mol. Biol. Evol. 21:1864-77.

Puillandre, N., Modica, M. V, Gustave, O., Place, L. L. \& West, C. P., 2012b. Large-scale species delimitation method for hyperdiverse groups. Mol. Ecol. 21:2671-91.

R Development Core Team, 2019. R: A language and environment for statistical computing.

Vienna, Austria: R Foundation for Statistical Computing. Retrieved from https://www.r-

project.org/

Rambaut, A., Drummond, A., 2007. Tracer version 1.5. Available at: http://beast.bio. ed.ac.uk/Tracer (Last accessed 18 February 2020).

Rannala, B. 2015. The art and science of species delimitation. Curr. Zool. 61:846-53

Reid, N. M. \& Carstens, B. C. 2012. Phylogenetic estimation error can decrease the accuracy of species delimitation : a Bayesian implementation of the general mixed Yule-coalescent model. BMC Evol. Biol. 12:196.

Ronquist, F. \& Huelsenbeck, J. P. 2003. MrBayes 3: Bayesian phylogenetic inference under mixed models. Bioinformatics 19:1572-4.

Ross, K. G., Gotzek, D., Ascunce, M. S., \& Shoemaker, D. D. 2010. Species delimitation: A case study in a problematic ant taxon. Syst. Biol. 59:162-84.

Saunders, G. W., \& Kucera, H. 2010. An evaluation of $r b c$ L, tufA, UPA, LSU and ITS as DNA barcode markers for the marine green macroalgae. Cryptogamie Algol. 31:487-528. Sauvage, T., Payri, C., Draisma, S. G., Prud'Homme van Reine, W. F., Verbruggen, H., Belton, G. S., Gurgel, F. D., Gabriel D., Sherwood A. R. \& Fredericq S., 2013. Molecular diversity of the Caulerpa racemosa-Caulerpa peltata complex (Caulerpaceae, Bryopsidales) in New Caledonia, with new Australasian records for C. racemosa var. cylindracea. Phycologia 52:6-13.

Sauvage, T., Schmidt, W. E., Suda, S., \& Fredericq, S. 2016. A metabarcoding framework for facilitated survey of endolithic phototrophs with tufA. BMC Ecol. 16:1-21. 
1039

1040

1041

1042

1043

1044

1045

1046

1047

1048

1049

1050

1051

1052

1053

1054

1055

1056

1057

1058

1059

1060

1061

1062

1063

Silberfeld, T., Leigh, J. W., Verbruggen, H., Cruaud, C., de Reviers, B., \& Rousseau, F. 2010.

A multi-locus time-calibrated phylogeny of the brown algae (Heterokonta, Ochrophyta,

Phaeophyceae): Investigating the evolutionary nature of the "brown algal crown radiation.”

Mol. Phylogenet. Evol. 56:659-74.

Stamatakis, A. 2014. RAxML version 8: a tool for phylogenetic analysis and post-analysis of large phylogenies. Bioinformatics 30:1312-13

Talavera, G., Dinc, V. \& Vila, R. 2013. Factors affecting species delimitations with the

GMYC model : insights from a butterfly survey, Methods Ecol. Evol. 4:1101-10.

Tamura, K., Stecher, G., Peterson, D., Filipski, A. \& Kumar, S. 2013. MEGA6: Molecular

Evolutionary Genetics Analysis version 6.0. Mol. Biol. Evol. 30:2725-9.

Tanaka, T. 1963. Studies on some marine algae from Southern Japan. IV. Mem. Fac. Fish.

Kagoshima Univ. 12:1-6.

Taylor, W. R. 1950. Plants of Bikini and other northern Marshall Islands. Ann Arbor:

University of Michigan Press. 227 pp, 79 pls.

Thiers, B., 2021. Index Herbariorum: A Global Directory of Public Herbaria and Associated Staff. New York Botanical Garden’s Virtual Herbarium.

Titlyanova, T. V., Perestenko, L. P. \& Kalugina-Gutnik, A. 1992. Catalogus algarum benthicarum ac berbarium Insularum Seychellarum (Oceanus Indicus). Nov. Sist. 28:40-47. Tsuda, R. T. 1972. Some marine benthic algae from Truk and Kuop, Caroline Islands. Atoll Res. Bull. 155:1-10.

Verbruggen, H., De Clerck, O., Cocquyt, E., Kooistra, W. H. C. F. \& Coppejans, E. 2005 a. Morphometric taxonomy of siphonous green algae: a methodological study within the genus Halimeda (Bryopsidales). J. Phycol. 41:126-39.

Verbruggen, H., De Clerck, O., Kooistra, W. H. C. F. \& Coppejans, E. 2005b. Molecular and morphometric data pinpoint species boundaries in Halimeda section Rhipsalis (Bryopsidales, 
Chlorophyta). J. Phycol. 41:606-21.

Verbruggen, H., Leliaert, F., Maggs, C. A., Shimada, S., Schils, T., Provan, J., Booth, D., Murphy, S., De Clerck, O., Littler, D. S., Littler, M. M., \& Coppejans, E. 2007. Species boundaries and phylogenetic relationships within the green algal genus Codium (Bryopsidales) based on plastid DNA sequences. Mol. Phylogenet. Evol. 44:240-54.

Verbruggen, H., Vlaeminck, C., Sauvage, T., Sherwood, A. R., Leliaert, F. \& De Clerck, O. 2009a. Phylogenetic analysis of Pseudochlorodesmis strains reveals cryptic diversity above the family level in the siphonous green algae (Bryopsidales, Chlorophyta). J. Phycol. 45:72631.

Verbruggen, H., Tyberghein, L., Pauly, K., Vlaeminck, C., Nieuwenhuyze, K. Van, Kooistra, W. H. C. F., Leliaert, F., \& Clerck, O. De. 2009b. Macroecology meets macroevolution: evolutionary niche dynamics in the seaweed Halimeda. Global Ecol. Biogeogr. 18:393-405. Verbruggen, H., Ashworth, M., LoDuca, S. T., Vlaeminck, C., Cocquyt, E., Sauvage, T., Zechman, F. W., Littler, D. S., Littler, M. M., Leliaert, F. \& De Clerck, O. 2009c. A multilocus time-calibrated phylogeny of the siphonous green algae. Mol. Phylogenet. Evol. 50:64253.

Verbruggen, H. \& Schils, T. 2012. Rhipilia coppejansii, a new coral reef-associated species from Guam (Bryopsidales, Chlorophyta). J. Phycol. 48:1090-8.

Vieira, C., D’hondt, S., De Clerck, O., \& Payri, C. E. 2014. Toward an inordinate fondness for stars, beetles and Lobophora ? Species diversity of the genus Lobophora (Dictyotales, Phaeophyceae) in New Caledonia. J. Phycol. 50:1101-19.

Vieira, C., Camacho, O., Sun, Z., Fredericq, S., Leliaert, F., Payri, C., \& De Clerck, O. 2017. Historical biogeography of the highly diverse brown seaweed Lobophora (Dictyotales, Phaeophyceae). Mol. Phylogenet. Evol., 110:81-92.

Vieira, C., Steen, F., D’hondt, S., Bafort, Q., Tyberghein, L., Fernandez-García, C., Wysor, 
B., Tronholm, A., Mattio, L., Payri, C., Kawai, H., Saunders, G., Leliaert, F., Verbruggen, H., \& De Clerck, O. 2021. Global biogeography and diversification of a group of brown seaweeds (Phaeophyceae) driven by clade-specific evolutionary processes. J. Biogeogr., 48:703-15.

Wiens, J. J., \& Servedio, M. R. 2000. Species delimitation in systematics : inferring diagnostic differences between species. Proc. R. Soc. Lond. B-Biol. Sci. 267:631-6.

Wiens, J. J. 2007. Species delimitation: new approaches for discovering diversity. Syst. Biol.

$1095 \quad 56: 875-8$.

Will, K. W., Mishler, B. D., \& Wheeler, Q. D. 2005. The perils of DNA barcoding and the need for integrative taxonomy. Syst. Biol. 54:844-51.

Womersley, H. B. S. 1984. The marine benthic flora of southern Australia. Part I.,

1099 Government Printer, Adelaide, 329 pp

Zhang, J., Kapli, P., Pavlidis, P. \& Stamatakis, A. 2013. A general species delimitation method with applications to phylogenetic placements. Bioinformatics 29:2869-76. coalescent, distance and character-based approaches for barcoding microalgaes: a test with

1104 Chlorella-like species (Chlorophyta). Plos One 11:e0153833. 
1107 Table 1: Summary of the number of hypotheses delimited for each method applied to the tufA 1108 and $r b c L$ datasets (alternative (b)GMYC partitions are indicated between brackets), including 1109 the number of singletons and summary of the number of PSHs common to all methods for 1110 each marker.

\begin{tabular}{|c|c|c|c|c|c|c|}
\hline Methods & & GMYC & bGMYC & hPTP & mPTP & ABGD \\
\hline \multirow{2}{*}{$\begin{array}{l}\text { Number of delimited } \\
\text { PSHs | number of }\end{array}$} & tufA & $48 \mid 7$ & (33)43|4 & $31 \mid 7$ & $37 \mid 5$ & $39 \mid 3$ \\
\hline & $r b c \mathrm{~L}$ & $47 \mid 10$ & $37 \mid 8$ & $31 \mid 12$ & $41 \mid 12$ & $42 \mid 9$ \\
\hline & bGMYC & \begin{tabular}{l|l}
38 & 30
\end{tabular} & & & & \\
\hline \multirow{3}{*}{$\begin{array}{l}\text { PSHs in common } \\
\text { (tufA } \mid r b c \mathrm{~L})\end{array}$} & hPTP & $20 \mid 19$ & $19 \mid 22$ & & & \\
\hline & mPTP & $32 \mid 28$ & $32 \mid 30$ & $19 \mid 23$ & & \\
\hline & ABGD & $32 \mid 27$ & $36 \mid 33$ & $16 \mid 21$ & $30 \mid 30$ & \\
\hline
\end{tabular}


1113 Figure 1: ML phylogeny of tribe Rhipileae obtained from the multilocus matrix (tufA, $r b c \mathrm{~L}$, 1114 and 18S rDNA), with bootstraps and posterior probabilities indicated at the nodes (bs/PP). 1115 Species of the same genus (as recognized by Guiry and Guiry (searched on the $10^{\text {th }}$ of 1116 December 2019)) are noted using the same color. The type species of Rhipilia is indicated in 1117 bold. Outgroup species: Caulerpa taxifolia, Caulerpa cupressoides and Caulerpa verticillata. Figure 2: ML phylogeny of "Rhipiliopsideae group 1" and "Rhipiliopsideae group 2” obtained from the multilocus matrix (tufA, $r b c \mathrm{~L}$, and $18 \mathrm{~S}$ rDNA), with bootstraps and posterior probabilities indicated at the nodes (bs/PP). Species of the same genus (as recognized by Guiry and Guiry (searched on the $10^{\text {th }}$ of December 2019) are noted using the same color: Outgroup species: Caulerpa taxifolia, Caulerpa sertularioides and Caulerpa verticillata.

Figure 3: Bayesian phylogeny of Rhipilia obtained from the multilocus matrix (tufA, $r b c \mathrm{~L}$, and 18S rDNA), with bootstraps and posterior probabilities indicated at the nodes (bs/PP). Species delimitation results obtained using the five methods applied to tufA and $r b c \mathrm{~L}$ markers are shown in the middle section, with species names and illustrations. Distribution of species (from molecular data + type localities) is shown on the map to the right ( $\mathrm{A}=$ Rhipilia penicilloides; $\mathrm{C}=R . \mathrm{sp} 1 ; \mathrm{D}=R$. diaphana; $\mathrm{F}=R$. sp3). Outgroup species: Rhipiliella verticillata, Kraftalia gracilis and Kraftalia orientalis. Image rights: Payri C.E.; * from Littler and Littler (2000).

Figure 4: ML phylogeny of Kraftalia gen. nov. obtained from the multilocus matrix (tufA, $r b c \mathrm{~L}$, and 18S rDNA), with bootstraps and posterior probabilities indicated at the nodes (bs/PP). Species delimitation results obtained using the five methods applied to tufA and $r b c \mathrm{~L}$ markers are shown in the middle section, with species names and illustrations. Distribution of the species (from molecular data + type localities) is shown on the map to the right $(\mathrm{A}=$ 
Kraftalia crassa; $\mathrm{B}=K . \mathrm{sp} 1 ; \mathrm{C}=:$ K. sp2; $\mathrm{D}=$ K. orientalis; $\mathrm{E}=K . \mathrm{sp} 3 ; \mathrm{H}=K$. yaeyamensis; $\mathrm{I}=$ K. sp4; J = K. gracilis; $\mathrm{K}=$ K. sp5). Outgroup species: Caulerpa taxifolia, Caulerpa verticillata, Rhipilia penicilloides, $R$. coppejansii, $R$. sp1 and $R$. sp3. Image rights: Payri C.E.

Figure 5: ML phylogeny of Rhipiliopsis obtained from the multilocus matrix (tufA, $r b c \mathrm{~L}$, and 18S rDNA), with bootstraps and posterior probabilities indicated at the nodes (bs/PP). Species delimitation results obtained using the five methods applied to tufA and $r b c \mathrm{~L}$ markers are shown to the right, with species names and illustrations. Distribution of the species (from molecular data + type localities $)$ is shown on the map at the bottom $(\mathrm{A}=R . \mathrm{sp} 5 ; \mathrm{B}=R . \mathrm{sp} 7)$. Outgroup taxa: Rhipilia penicilloides, Kraftalia orientalis and Rhipiliella verticillata. Images rights: Payri, C.E.; * from Algaebase; ** from Littler and Littler (2000).

Figure 6: ML phylogeny of Rhipiliospina gen. nov. and Callipsygma obtained from the multilocus matrix (tufA, $r b c \mathrm{~L}$, and $18 \mathrm{~S}$ rDNA) with bootstraps and posterior probabilities indicated at nodes (bs/PP). Species delimitation results obtained using the five methods applied to tufA and $r b c \mathrm{~L}$ markers are shown in the middle section, with species names and illustrations. Distribution of the species (from molecular data + type localities) is shown on the map to the right $(\mathrm{C}=$ Rhipiliospina sp6; $\mathrm{D}=R$. sp2; $\mathrm{E}=R . \mathrm{sp} 1 ; \mathrm{F}=R . \mathrm{sp} 3 ; \mathrm{G}=R . \mathrm{sp} 4 ; \mathrm{I}=R$. sp7). Outgroup species: Caulerpa taxifolia, Caulerpa verticillata, Caulerpa sertularioides. Image rights: Payri, C.E.; *: from Cremen and al. (2019).

Figure 7: Kraftalia gen. nov. A-E: Species external habit, A: K. orientalis (NOU 204095), B: K crassa (NOU 203593), C: K. gracilis (NOU 203756), D: K. yaeyamensis (NOU 203801), E: K. sp5 (NOU 203798); F: Siphons disposition in K orientalis (NOU 204123); G: Dichotomies with bulge and constrictions in K. crassa (NOU 203483); H: Siphons disposition in K gracilis (NOU 203320); I: Siphons disposition in K. yaeyamensis (NOU 203816); J: Siphons disposition in K. sp5 (NOU 203798); K-O: Adhesion structures between siphons: K and L : Tenacula in K. orientalis (NOU 204123) and K. crassa (NOU 203593), 
respectively; M: Differentiated bent siphon apices on one of the two dichotomous branches (circles); arising from unconstricted dichotomies (arrows) in K. gracilis (NOU 203320), $\mathbf{N}$ : Direct contact between siphons in K. yaeyamensis (NOU 203816), O: Unilateral papillae in K. sp5 (NOU 203798); Scale bars: A: 1.5 cm ; B: 6.5 mm; C: 1 mm; D: 900 um; E: 1.5 mm; F: $115 \mu \mathrm{m}$; G: $55 \mu \mathrm{m}$; H: $180 \mu \mathrm{m}$; I: $200 \mu \mathrm{m}$; J: $250 \mu \mathrm{m}$; K: $40 \mu \mathrm{m}$; L: $60 \mu \mathrm{m} ; \mathrm{M}: 40 \mu \mathrm{m}$; N: $40 \mu \mathrm{m} ; \mathrm{O}: 33 \mu \mathrm{m}$.

Figure 8: Rhipiliospina stellifera sp. nov. A-C : Habit of the plant, A: NOU 203095, B: NOU 203758, C: NOU 203764; D-G: Stipe with spinous or star-shaped cortication, D and F: NOU 203095, E and G: NOU 203758; H: Spinous protuberances in siphons from the basal part of the blade (NOU 203095); I: Net-like aspect of the blade (NOU 203095); J: Tortuous siphons dichotomously divided and adhering to each other with papillae (NOU 203758); H:

Dichotomies with symmetrical constrictions and adhesion between siphons with bilateral papillae forming H structures (NOU 203758). Scale bars: A: $1 \mathrm{~mm}$; B: $1.5 \mathrm{~mm}$; C: $125 \mathrm{~mm}$; D: $100 \mu \mathrm{m}$; E: $115 \mu \mathrm{m}$; F: $50 \mu \mathrm{m}$; G: $40 \mu \mathrm{m}$; H: $50 \mu \mathrm{m}$; I: $300 \mu \mathrm{m}$; J: $130 \mu \mathrm{m} ; \mathrm{K}: 25 \mu \mathrm{m}$. Figure 9: Callipsygma brevis sp. nov. A: Habitat of the species (in Madagascar); B: External habit of the species in-situ; C-D: External habit of the species ex-situ; E: Stipe siphons with protuberances and deformed lateral branches; F: Dichotomies with symmetrical constrictions and ring of cell-wall thickening; G: Cohesion between siphons with uni- or bilateral papillae; H: Overview of siphons dichotomously divided and adhering by papillae. Scale bars: A: 4cm; B: 1.25 cm; C: 0.8 cm; D: 1.25 cm; E: $85 \mu \mathrm{m}$; F: $45.5 \mu \mathrm{m}$; G: $100 \mu \mathrm{m}$; H: $100 \mu \mathrm{m}$. 
Appendix S1: Species delimitation analyses of the tufA datasets

Appendix S2: Supports (ML) of hPTP partitions for the tufA datasets

Appendix S3: Species delimitation analyses of the $r b c \mathrm{~L}$ datasets

Appendix S4: Supports (ML) of hPTP partitions for the $r b c L$ datasets

Figure S1: Phylogenetic relationships among suborder Halimedineae obtained from the concatenated multilocus matrix (tufA, $r b c \mathrm{~L}, 18 \mathrm{~S}$ rDNA), and position of the former Rhipiliaceae lineages (light green). Values at nodes indicate bootstraps and posterior plumosa.

Figure S2: Species delimitation results for tribe Rhipileae obtained with the five methods morpho-anatomical observations.

Figure S3: Species delimitation results for "Rhipiliopsideae group 1" obtained with the five methods (ABGD, GMYC, bGMYC, PTP and mPTP) on the tufA dataset. Partitions retained as SSHs following the majority rule are indicated by black bars, while grey bars are the different partitions not retained. The defined SSHs (= clades) are indicated in the right column, together with species assignments obtained from morpho-anatomical observations. 
Figure S4: Species delimitation results for "Rhipiliopsideae group 2" obtained with the five methods (ABGD, GMYC, bGMYC, PTP and mPTP) on the tufA dataset. Partitions retained as SSHs following the majority rule are indicated by black bars, while grey bars are the different partitions not retained. The defined SSHs (= clades) are indicated in the right column, together with species assignments obtained from morpho-anatomical observations.

Figure S5: Species delimitation results for tribe Rhipileae obtained with the five methods (ABGD, GMYC, bGMYC, PTP and mPTP) on the $r b c L$ dataset. Partitions retained as SSHs following the majority rule are indicated by black bars, while grey bars are the different partitions not retained. The defined SSHs (= clades) are indicated in the right column, together with species assignments obtained from morpho-anatomical observations.

Figure S6: Species delimitation results for Rhipiliopsideae lineages (group 1 \& 2) obtained with the five methods (ABGD, GMYC, bGMYC, PTP and mPTP) on the $r b c \mathrm{~L}$ dataset. The tree represented is MCCT tree from the BEAST analysis. Partitions retained as SSHs following the majority rule are indicated by black bars. Blue bars represent the partition retained as SSHs, although not in the majority rule, while grey bars are the different partitions not retained. The defined SSHs (= clades) are indicated in the right column, together with species assignments obtained from morpho-anatomical observations.

Figure S7 : ML phylogeny of other Rhipileae species, including Rhipiliella verticillata, obtained from the multilocus matrix (tufA, $r b c \mathrm{~L}$ and $18 \mathrm{~S}$ rDNA), with bootstraps and posterior probabilities indicated at the nodes (bs/PP). The species delimitation results obtained using the five methods applied to tufA and $r b c \mathrm{~L}$ markers are shown in the middle section, with species names and illustrations. The distribution of the species (from molecular data + type localities $)$ is shown on the map to the right $(\mathrm{A}=$ Rhipiliella verticillata; $\mathrm{B}=$ Rhipiliopsis cf. mortensenii). Outgroup species: Caulerpa taxifolia, Caulerpa verticillata, Rhipilia 
penicilloides, $R$. coppejansii, $R$. sp1 and $R$. sp3. Image rights: * from Littler and Littler

1231 (2000); ** from Womersley, 1984.

1232 Table S1: List of specimens with sample ID, species identification, location of sampling, 1233 GenBank accession numbers (or BOLD sequence ID for those not submitted), and the 1234 sequences used in the species delimitation approach and the corresponding SSH number.

1235 Table S2: Primers used for the amplification of $t u f A, r b c L$, and $18 S$ rDNA markers

1236 Table S3: Details of phylogenetic analysis for both ML and BI reconstructions according to the 1237 various datasets.

1238 Table S4: Variability of the datasets.

1239 Table S5: A posteriori probabilities (PP) of the partitions defined by the bGMYC method on 1240 the tufA marker for Rhipileae and Rhipiliopsideae lineages.

1241 Table S6: A posteriori probabilities (PP) of the partitions defined by the bGMYC method on 1242 the $r b c \mathrm{~L}$ marker for Rhipileae and Rhipiliopsideae lineages.

1243 Table S7: Details of the incongruence resolution process and species assignment of the SSHs. 


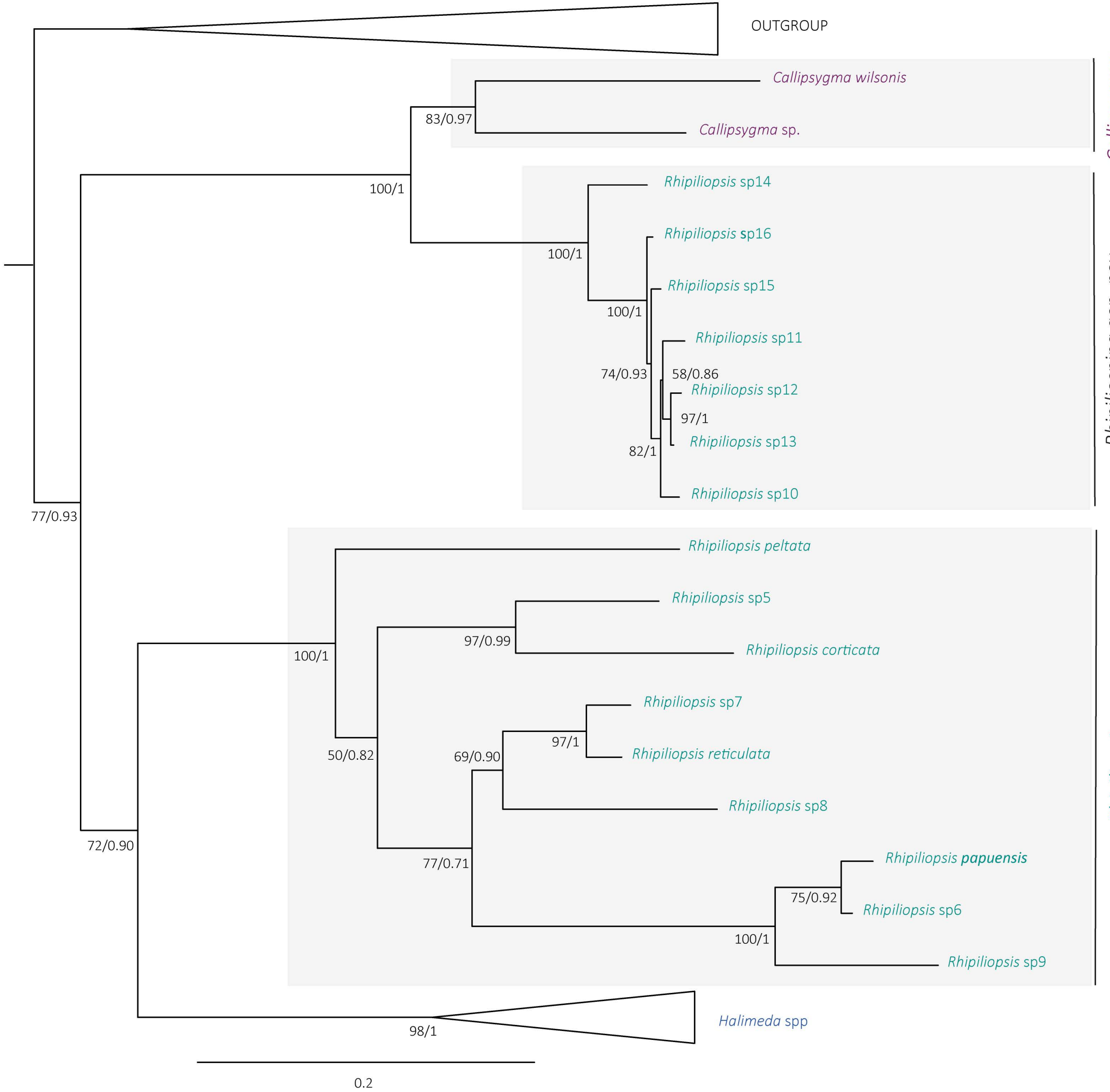




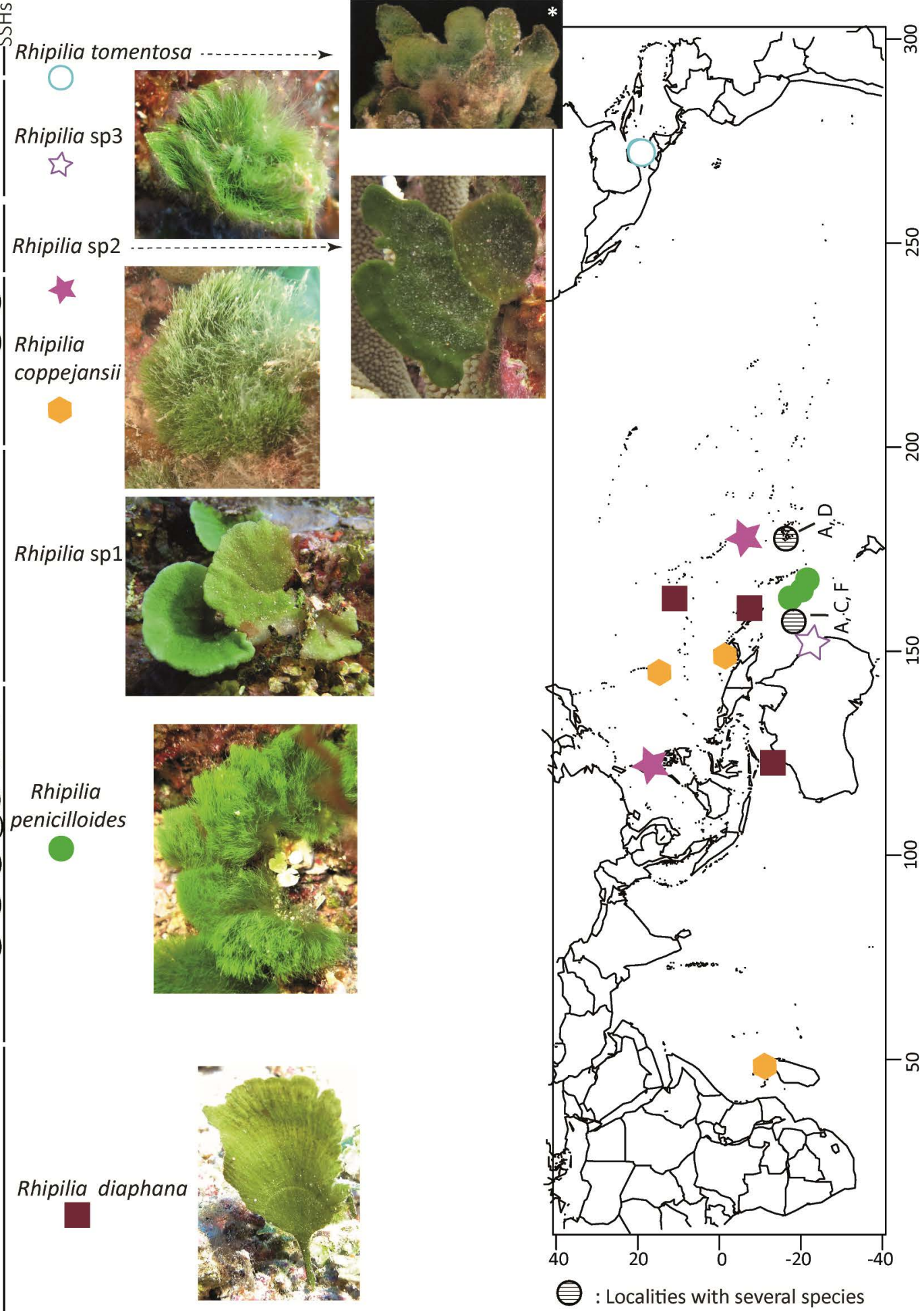


100/1 KKraftalia sp3 NOU203766 (New Caledonia)

Kraftalia sp3

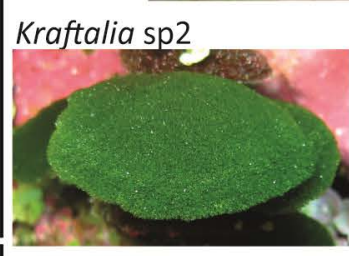

Kraftalia orientalis

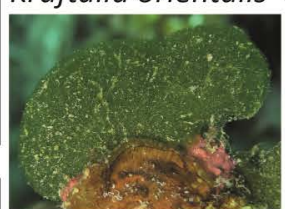

Kraftalia sp1

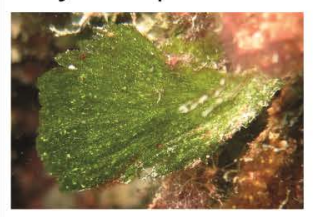

91/1 Kraftalia sp1 NOU203000 (New Caledonia) 68/0.62 Kraftalia sp1 NOU203367 (Papua New-Guinea)

92/1 Kraftalia sp1 NOU203371 (Papua New-Guinea)

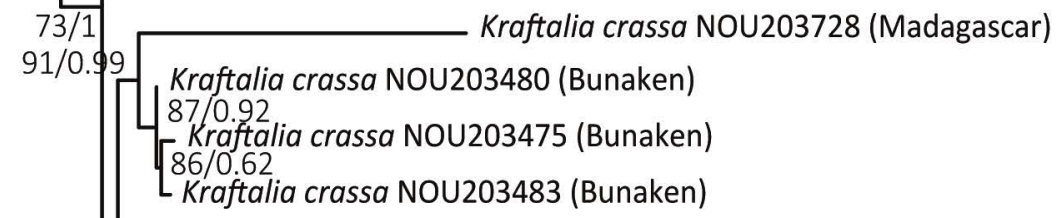

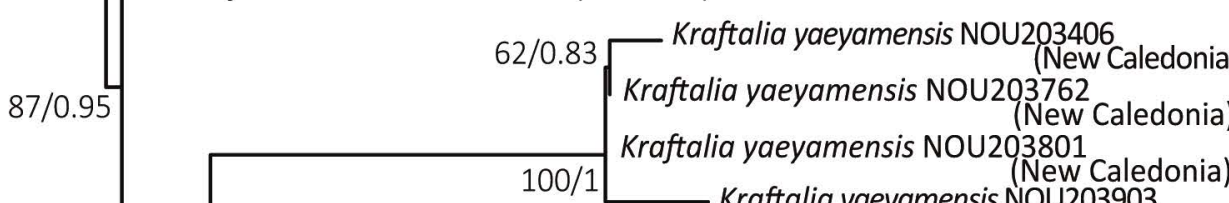
Kraftalia yaeyamensis NOU203903

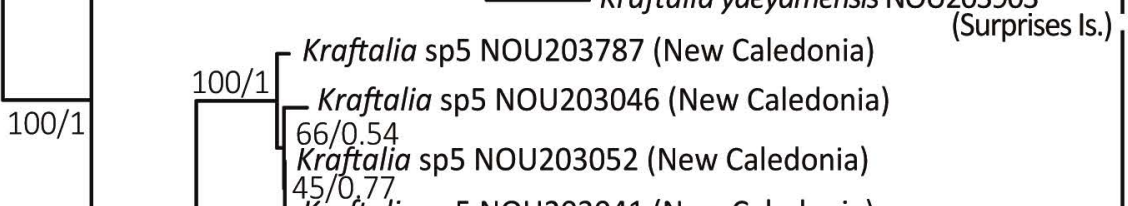

100/1 $100 / 1\left[\begin{array}{l}\text { Kraftalia sp4 NOU203372 (Papua New-Guinea) } \\ \text { Kraftalia sp4 NOU203363 (Papua New-Guinea) }\end{array}\right.$

Kraftalia sp5 NOU203041 (New Caledonia)

$100 / 1$

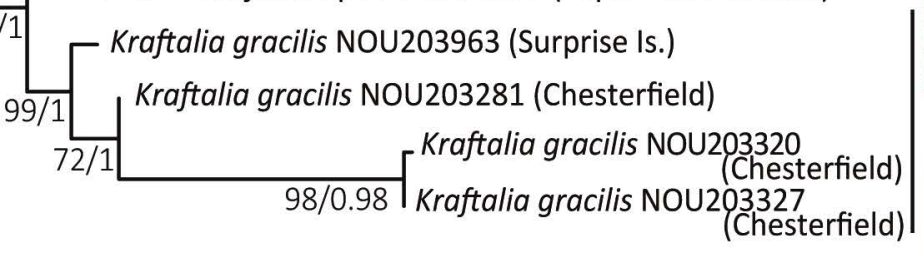

Kraftalia gracilis NOU203963 (Surprise Is.)
98/0.98 $\left[\begin{array}{l}\text { Kraftalia gracilis NOU203320 } \\ \text { Kraftalia gracilis NOU203327 } \\ \text { (Chestield) }\end{array}\right)$

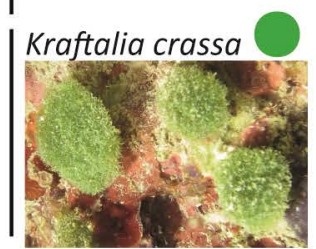

Kraftalia

yaeyamensis

Kraftalia sp5

Kraftalia sp4

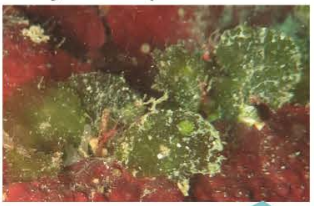

Kraftalia gracilis

Localities with several species

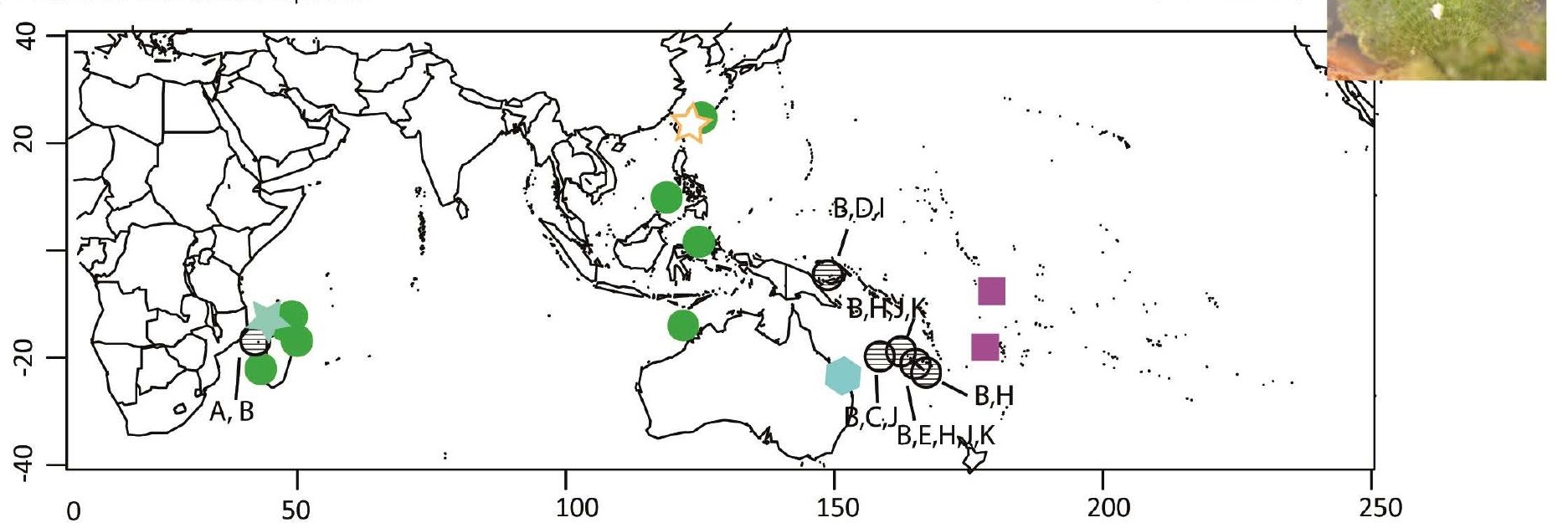


98/0.97 Rhipiliospina stellifera NOU203764 (New Caledonia)

Rhipiliospina sp2 NOU203012 (New Caledonia)

60/100/1 Rhipiliospina sp2 NOU203439 (New Caledonia) Rhipiliospina sp1 NOU203800 (New Caledonia)

40/- Rhipiliospina sp3 NOU203822 (New Caledonia) $100 / 1$

Rhipiliospina sp3 NoU203071 (New Caledonia)

Rhipiliospina sp4 NOU203747 (New Caledonia)
99/1 Rhipiliospina sp4 NOU203905 (Surprise Is.)

$79 / 0.95$

\begin{tabular}{l}
89 \\
\hline $1 \quad$ 89/1 Rhipiliospina sp4 NOU203971 (Surprise Is.) \\
Rhipiliospina sp4 NOU203989 (Surprise
\end{tabular}

Rhipiliospina sp4 NOU203753 (New Caledonia)

Rhipiliospina sp4 NOU203017 (New Caledonia)

Rhipiliospina sp4 NOU203018 (New Caledonia)

Rhipiliospina sp5 NOU203636 (Madagascar)

100/1 Rhipiliospina sp5 NOU203741 (Madagascar)

88/1 Rhipiliospina sp6 NOU203149 (Chesterfield)

77/0.86 Rhipiliospina sp6 NOU203145 (Chesterfield)

Rhipiliospina sp6 NOU203148 (Chesterfield)

Rhipiliospina sp6 NOU203146 (Chesterfield)

Rhipiliospina sp6 NoU203147 (Chesterfield)

Rhipiliospina sp6 NOU203113 (Chesterfield)

Rhipiliospina sp6 NOU203125 (Chesterfield)

Rhipiliospina sp6 NOU203150 (Chesterfield)

Rhipiliospina sp6 NOU203114 (Chesterfield)

$100 / 1$

Rhipiliospina sp6 NOU203133 (Chesterfield)

Rhipiliospina sp6 NOU203112 (Chesterfield)

- Rhipiliospina sp6 NOU203228 (Chesterfield)

- Rhipiliospina sp6 NOU203199 (Chesterfield)

Rhipiliospina sp6 NOU203326 (Chesterfield)

Rhipiliospina sp6 NOU203156 (Chesterfield)

Rhipiliospina sp6 NOU203200 (Chesterfield)

Rhipiliospina sp6 NOU203957 (Surprise Is.)
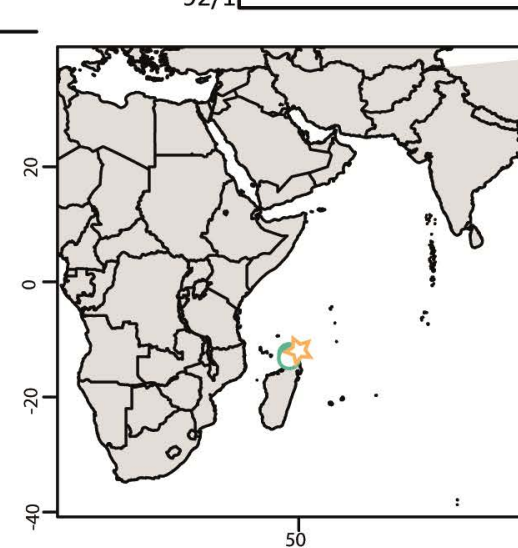

1 150 द्दु (Madagascar) arevis sp. nov.

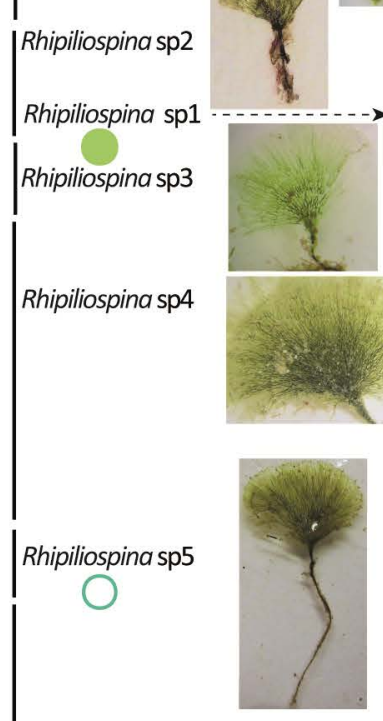

Rhipiliospina stellifera sp. nov.

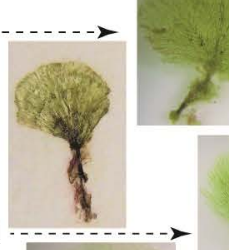

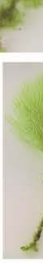
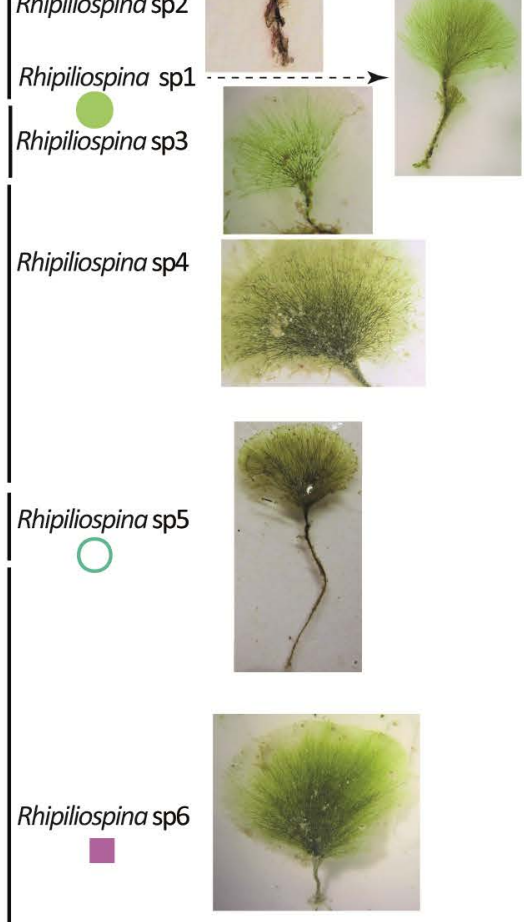

: Localities with several species 


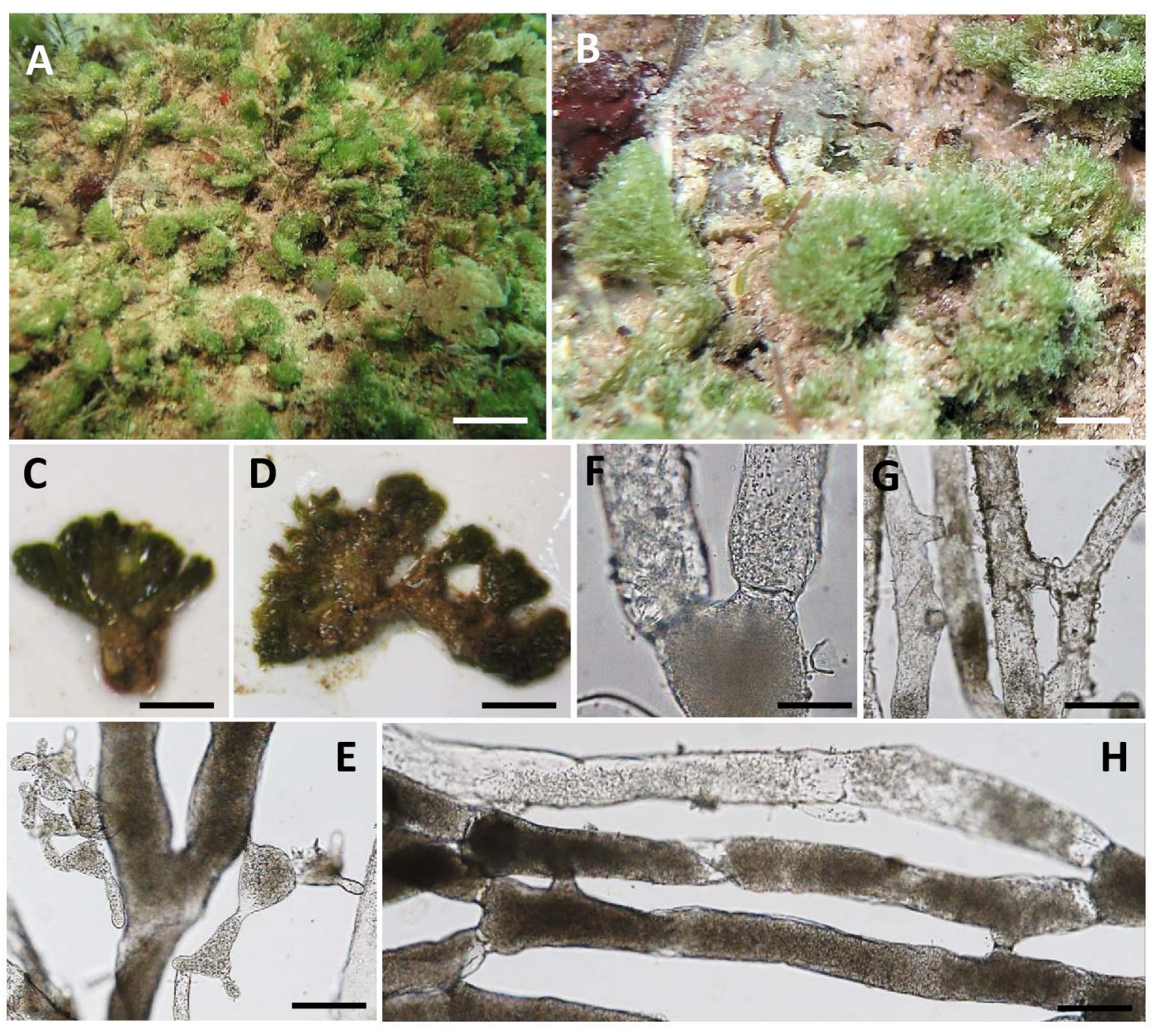

